\title{
12. RADIOLARIAN BIOSTRATIGRAPHY FROM LEG 112 ON THE PERU MARGIN1
}

\author{
P. De Wever, ${ }^{2}$ J.-P. Caulet, ${ }^{3}$ and J. Bourgois ${ }^{4}$
}

\begin{abstract}
The radiolarian fauna found at the 10 sites drilled during Ocean Drilling Program (ODP) Leg 112 range in age from Eocene to Holocene. Relatively abundant and well-preserved assemblages are present in Sites $682,683,685$, and 688. Occurrence tables of 175 species are presented for these sites. For each site, stratigraphic results are summarized in two figures showing the radiolarian biozonation, the inferred hiatuses, and barren intervals. The Pliocene/Pleistocene and Miocene/Pliocene boundaries were not recognized from radiolarian stratigraphy. Pleistocene and middle Miocene radiolarian assemblages are generally abundant and well preserved. New stratigraphic data are given for some rarely described species, such as Cypassis irregularis, Lamprocyrtis daniellae, Plectacantha cresmatoplegma, Pterocanium grandiporus, Pseudocubus warreni, and Phormostichoartus (?) crustula.
\end{abstract}

\section{INTRODUCTION}

JOIDES Resolution departed Callao, Peru, in October 1986 to drill 27 holes at 10 sites on the Andean continental margin off Peru. Two processes, coastal upwelling and plate subduction, shaped this margin and its sediments since Eocene time; these processes were of interest to us.

During Leg 112, drilling was concentrated along two seismic corridors perpendicular to the trench axis off Peru. The northern corridor (near $9^{\circ} \mathrm{S}$ off Trujillo, central Peru) was cored at three ODP sites $(683,684,685$; Fig. 1$)$ to constrain previous seismic interpretations (von Huene et al., 1985). These sites are seaward of two industry drill holes (Delfin and Ballena) and landward of two DSDP Sites ( 320 and 321) on the Nazca Plate (see Suess, von Huene, et al., 1988). The southern corridor (near $11^{\circ} \mathrm{S}$ off Lima, central Peru) was cored at five sites $(679,680,681,682,688$; Fig.1) and provided stratigraphic control at both the seaward (Sites 682 and 688) and the landward ends (Site 679) of the Lima Basin. Results from drilling on either flank of the Lima Basin amplify the indication of subsidence, which had been previously deduced from dredging results. Two additional sites ( 686 and 687 near $13^{\circ} \mathrm{S}$ off Pisco) provided additional data for paleoenvironmental interpretation on a north-south transect. These sites reveal that the Quaternary sediment record thickens enormously southward-from $14 \mathrm{~m}$ in the north to more than $300 \mathrm{~m}$ in the south-and is tectonically controlled (see Suess, von Huene, et al., 1988).

Objectives of Leg 112 were both tectonic and paleoenvironmental. The tectonic objective was to test hypotheses inferred from geophysical data and conventional sampling along the Peru margin: (1) about the seaward extent of the continental crust, (2) the nature of the margin's junction with the accretionary complex, and (3) to relate the tectonic history of the continental margin to the plate convergence of the oceanic crust. The record of paleoenvironmental changes and the diagenetic process of the forearc basins are linked closely to the tectonic history of the margin.

\footnotetext{
${ }^{1}$ Suess, E., von Huene, R., et al., 1990. Proc. ODP, Sci. Results, 112: College Station, TX (Ocean Drilling Program).

2 CNRS, Université Pierre et Marie Curie, Laboratoire de Stratigraphie, T15-16 E4, 4 Place Jussieu, 75252 Paris Cedex 05, France.

${ }^{3}$ CNRS, Musée National d'Histoire Naturelle, Laboratoire de Géologie, 43 Rue Buffon, 75005 Paris, France.

${ }^{4}$ CNRS, Université Pierre et Marie Curie, Laboratoire de Géotectonique, T26-0 E1, 4 Place Jussieu, 75252 Paris Cedex O5, France.
}

Initiation of the eastern Pacific boundary current circulation and the associated wind system (a process that established the coastal upwelling regime during Miocene time) occurred during the subduction of the modern Nazca Plate beneath the South American craton, leading to the development of forearc basins (Pisco Basin, Lima Basin, Salaverry Basin, Trujillo Basin, etc.). Sedimentation in these elongated basins on the shelf and upper slope off Peru reflects vertical movement of the Andean margin basement and records the detailed oceanographic history of one of the best-developed coastal upwelling regimes (Suess and Thiede, 1983; Thiede and Suess, 1983).

Both the rapid vertical motion of forearc basins and the influx of biogenic matter from coastal upwelling mixed with terrigenous material generate an extreme range of chemical and sedimentological conditions that affect diagenesis. Leg 112 addresses this interplay between tectonic and oceanographic processes and their role in sedimentation and diagenesis of the forearc basins. The paleoenvironmental history is recorded in the sediment sequences drilled in the forearc basins and on the adjacent continental slope. Discovering the amplitude of vertical tectonic movement of these basins and the timing of these events were prime objectives. In addition, we wished to date the onset of coastal upwelling and to determine the response of the upwelling circulation regime to tectonic and climatic forcing.

Radiolarians were recovered from many levels of the deep sites (Figs. 2 and 3), but they are rare from shallow shelf sites. Radiolarian assemblages range in age from Eocene to Holocene, but the fauna is well preserved only in middle Miocene to Holocene sediments.

\section{METHODS}

Core-catcher samples were collected from every core recovered at all sites during Leg 112 . Samples were cleaned in boiling water and Calgon and, when necessary, in hot dilute hydrogen peroxide. Residue was sieved (at $63 \mu \mathrm{m}$ ) and the greater than $63-\mu \mathrm{m}$ particles were mounted on slides with Canada Balsam. For some samples from Sites 685 and 688, the techniques used for Mesozoic rocks (De Wever et al., 1979; De Wever, 1982) were employed to extract radiolarians. All sampled intervals were examined by the authors. Radiolarian findings for Sites $682,683,685$, and 688 are summarized in range charts showing all previously described species, general abundance and preservation of assemblages, and depth of penetration (Tables 1 through 4 ). These charts do not report 


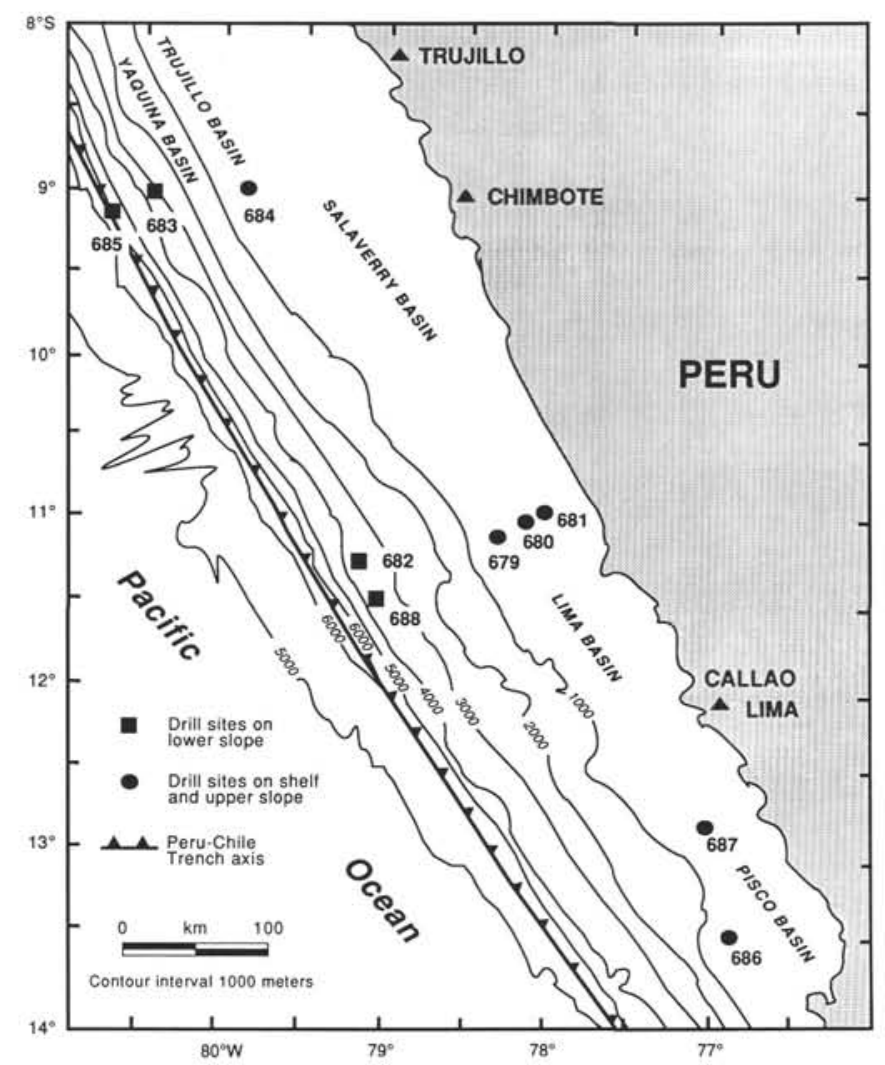

Figure 1. Locations of transects in the northern $\left(\mathrm{C}-\mathrm{D}, 9^{\circ} \mathrm{S}\right)$ and southern (A-B, $11^{\circ} 30^{\prime} \mathrm{S}$ ) areas of investigation, bathymetry, and location of sites drilled during Leg 112. Bathymetry in meters.

quantitative abundances, but rather, evaluate species on their presence or absence only.

\section{RADIOLARIANS AT EACH SITE}

The radiolarian zones used here (Figs. 4 and 5) for the last $4.5 \mathrm{~m} . \mathrm{y}$. are those of Johnson et al. (in press) and are designated by both NR numbers and specific names. The older zones are those defined by Riedel and Sanfilippo (1978). The reader should be cautioned that both these zonations contain $S$. peregrina Zones that are defined differently. We tried to use the radiolarian range charts published by Nigrini (1985). Unfortunately, most of the stratigraphic markers common in the central Pacific appear to be absent off the Peru margin. The biozonation proposed by Goll (1980) for the eastern tropical Pliocene and Pleistocene sediments was not used because many of his stratigraphic markers are not present in our material. As many hiatuses were noted and paleomagnetic control is poor, reliable ages for radiolarian events could not be determined. In some cases, the radiolarian assemblage is diluted by abundant diatoms.

\section{Site 679}

Site $679\left(11^{\circ} 03.52^{\prime} \mathrm{S}, 78^{\circ} 15.92^{\prime} \mathrm{W}\right)$ is located on the seaward edge of an outer-shelf mud lens that formed under the influence of the Peru coastal upwelling system. The compressed stratigraphic section contains a record of late Neogene and Quaternary coastal upwelling. Of the five holes drilled at Site 679 , two of them (Holes 679B and 679E) were studied for radiolarians. Radiolarians were observed only in Samples 112-679B-1H-CC (6.5 mbsf) and -2H-CC (16.0 mbsf). The presence of species such as Pterocorys minythorax, Cycla- dophora davisiana, Lamprocyclas junonis gr., and Octopyle stenozona gr. indicate a Quaternary age.

\section{Site 680}

Site $680\left(11^{\circ} 03.90^{\prime} \mathrm{S}, 78^{\circ} 04.67^{\prime} \mathrm{W}\right)$ is centered on an eastwest transect of three sites across the sedimentary sequence of the Peruvian outer shelf and upper slope deposited under strong coastal upwelling conditions. Three holes were drilled at Site 680.

Radiolarians are rare because of diatom dilution in Samples 112-680A-1H-CC (8.3 mbsf) to - $5 \mathrm{H}-\mathrm{CC}(46.3 \mathrm{mbsf})$ and Samples $112-680 \mathrm{~B}-1 \mathrm{H}-\mathrm{CC}(5.5 \mathrm{mbsf})$ to $2 \mathrm{H}-\mathrm{CC}$ ( $15.0 \mathrm{mbsf})$, but preservation is good. Species such as Dictyophimus infabricatus, Pterocanium grandiporus, $O$. stenozona gr., $P$. minythorax, Lamprocyrtis nigriniae, Botryostrobus seriatus, and Pterocanium korotnevi are characteristic of a late Pleistocene age. However, no detailed radiolarian zonation can be proposed because many deep living species, such as Stylatractus universus, probably never lived in such shallow waters above the continental shelf.

\section{Site 681}

Site $681\left(10^{\circ} 58.60^{\prime} \mathrm{S}, 77^{\circ} 57.46^{\prime} \mathrm{W}\right)$ is the most landward (and consequently the shallowest) of the three sites (679, 680,681 ) along the east-west transect crossing the upwelling deposits of the Peruvian shelf and upper slope. This site is also located nearest the origin of coastal upwelling centers associated with the headlands near $11^{\circ} \mathrm{S}$. The water depth at this site nearly coincides with the top of the oxygenminimum zone. Of the three holes drilled at Site 681, radiolarians were studied in core-catcher samples from Holes 681A and 681B.

Radiolarians are rare in Samples 112-681A-1H-CC $(6.5$ mbsf) to $-3 \mathrm{H}-\mathrm{CC}$ ( $25.5 \mathrm{mbsf})$. Species assemblages are typical of the upper Quaternary of the eastern Pacific. Representatives of the colonial form Acrosphaera murrayana appear to be abundant in this upwelling population. Reworked specimens of Phormostichoartus fistula were observed in Sample 112-681A-2H-CC (16.0 mbsf). In Hole 681B, radiolarians are rare in Samples 112-681B-1H-CC (5.9 mbsf) to -4H-CC (34.4 mbsf), but those present are indicative of a late Quaternary age.

\section{Site 682}

Site $682\left(11^{\circ} 15.99^{\prime} \mathrm{S}, 79^{\circ} 03.73^{\prime} \mathrm{W}\right)$ is located on the landward side of the lower slope of the Peru Trench at a water depth of $3788 \mathrm{~m}$. This part of the slope is considered more as a part of the Peruvian continental margin, before the Neogene Andean orogeny, than an element accreted during the orogeny.

Radiolarians are rare to few and are moderately to well preserved in the samples from Cores $112-682 \mathrm{~A}-1 \mathrm{H}$ to $-48 \mathrm{X}$. Many barren intervals were observed (see Table 1).

The Pleistocene period is condensed. Sample 112-682A$1 \mathrm{H}-\mathrm{CC}$ ( $9.9 \mathrm{mbsf})$ is related to Zones NR1/NR2 (Buccinosphaera invaginata and Collosphaera tuberosa Zones). The presence of S. universus, Phormostichoartus pitomorphus, Anthocyrtidium nosicaae, L. nigriniae, and Lamprocyrtis neoheteroporos places Samples 112-682A-2H-CC (19.3 mbsf) and $-3 \mathrm{H}-\mathrm{CC}$ ( $28.8 \mathrm{mbsf})$ in early to middle Pleistocene. The Pliocene/Pleistocene boundary could not be recognized because Pterocanium prismatium was not observed. The interval between Samples 112-682A-3H-CC (28.8 mbsf) and-7XCC $(66.8 \mathrm{mbsf})$ belongs to Zones NR6/NR7 ( $P$. prismatium and Anthocyrtidium jenghisi Zones), which are early Pleistocene and late Pliocene in age. This is based on the absence of $L$. nigriniae and the occurrence of $C$. davisiana, Theo- 


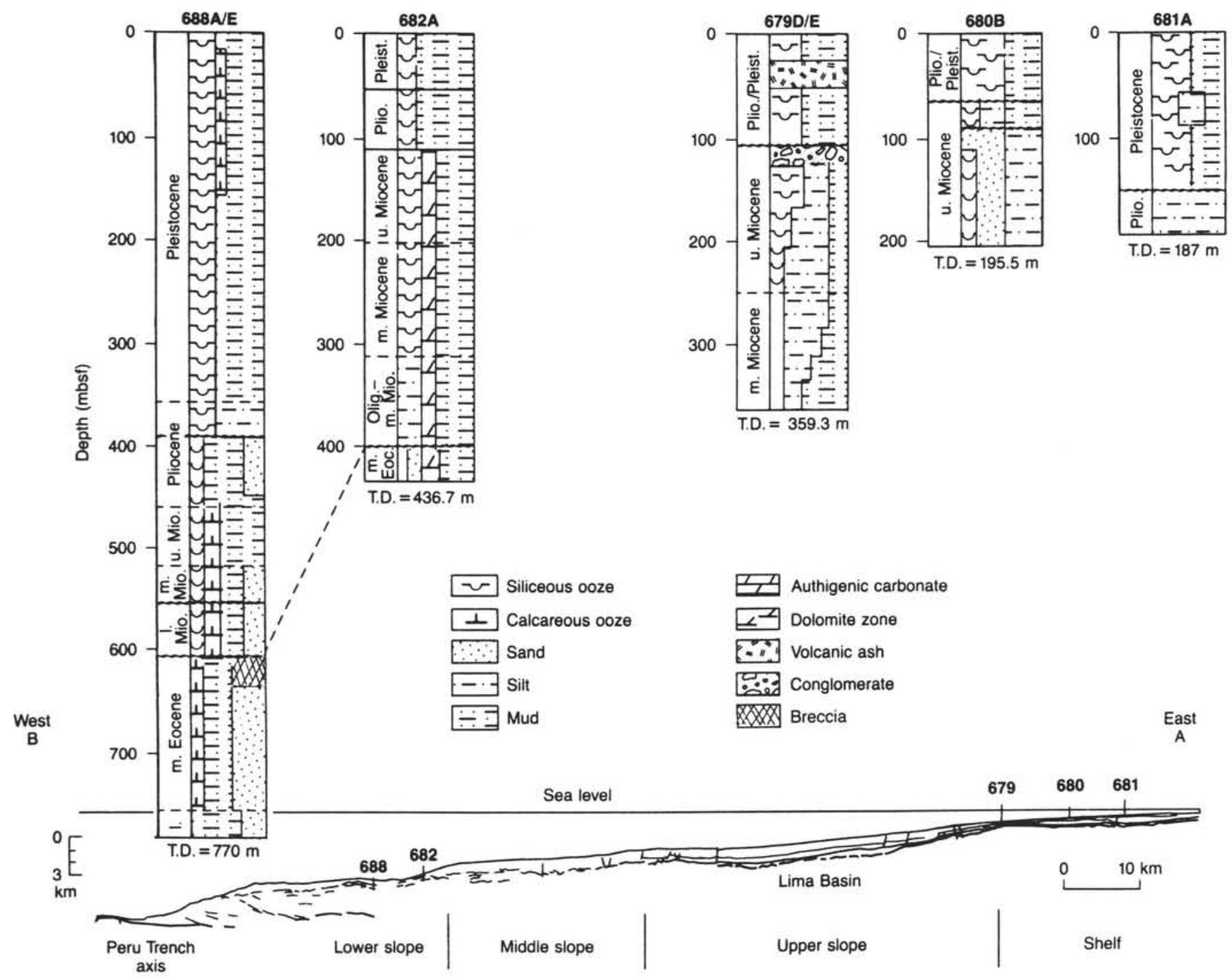

Figure 2. Simplified structural transect, based on seismic survey and results across the Peruvian margin at $11^{\circ} 30^{\prime} \mathrm{S}$.

corythium vetulum, and Anthocyrtidium ehrenbergi. The boundary between the two zones is not certain because of barren intervals and the absence of $P$. fistula.

In Sample 112-682A-8X-CC (76.3 mbsf), the last occurrences of Stichocorys peregrina and Anthocyrtidium pliocenica, combined with the absence of $L$. neoheteroporos and $C$. davisiana, are characteristic of an early Pliocene age. Rare specimens of Lamprocyrtis daniellae and Pseudocubus vema confirm an early Pliocene age for the interval between Samples 112-682A-8X-CC (76.3 mbsf) and -11X-CC (104.8 mbsf), which has been placed in the $S$. peregrina Zone of Riedel and Sanfilippo (1978).

Samples 112-682A-12X-CC (114.3 mbsf) through -19X-CC (180.8 mbsf) are barren of radiolarians. Radiolarians are rare and moderately preserved in Samples 112-682A-20X-CC (190.3 mbsf) to -23X-CC (218.8 mbsf). The presence of Didymocyrtis antepenultima and Diartus hughesi place these sediments in the early late Miocene $D$. antepenultima Zone.

Radiolarians are absent from Samples 112-682A-24X-CC (228.3 mbsf) to $-28 \mathrm{X}-\mathrm{CC}$ (266.3 mbsf). Few and moderately preserved forms recorded in Sample 112-682A-29X-CC (275.8 mbsf) are characteristic of the Diartus petterssoni Zone.

The radiolarian fauna is generally rare and poorly preserved downhole. Samples 112-682A-32X-CC (295.1 mbsf) and $-35 \mathrm{X}-\mathrm{CC}(320.7 \mathrm{mbsf})$ contain rare specimens that are indicative of the Didymocyrtis alata Zone. This age assignment is confirmed by an exceptionally abundant and wellpreserved assemblage in Sample 112-682A-34X-CC (311.2 mbsf), including Didymocyrtis mammifera, Didymocyrtis tubaria, Didymocyrtis violina, Dorcadospyris dentata, Liriospyris parkerae, and Stichocorys wolffii.

Rare and poorly preserved Eocene radiolarians were observed in the oldest sediments recovered in Hole 682A. Unfortunately, no zonation can be proposed for Samples 112-682A-46X-CC (417.7 mbsf) and -47X-CC (427.2 mbsf).

\section{Site 683}

Holes $683 \mathrm{~A}\left(9^{\circ} 01.69^{\prime} \mathrm{S}, 80^{\circ} 24.40^{\prime} \mathrm{W}\right)$ and $683 \mathrm{~B}\left(9^{\circ} 01.59^{\prime} \mathrm{S}\right.$, $80^{\circ} 24.26^{\prime} \mathrm{W}$ ) were drilled in lower-slope sediments of the Peru continental margin (off the Yaquian Basin). The setting is similar to that at Site 682 except that the water depth at Site 683 is about $3080 \mathrm{~m}$, whereas at Site 682 it is about $3800 \mathrm{~m}$.

The upper part of Hole $683 \mathrm{~A}$ contains an abundant and well-preserved radiolarian fauna of Holocene age. The last occurrence of $S$. universus in Sample 112-683A-6H-CC (49.7 mbsf) places this sample in Zone NR3 ( $S$. universus Zone). The absence of $B$. invaginata in Peru margin material does not permit us to discriminate between Zones NR1 ( $B$. invaginata 


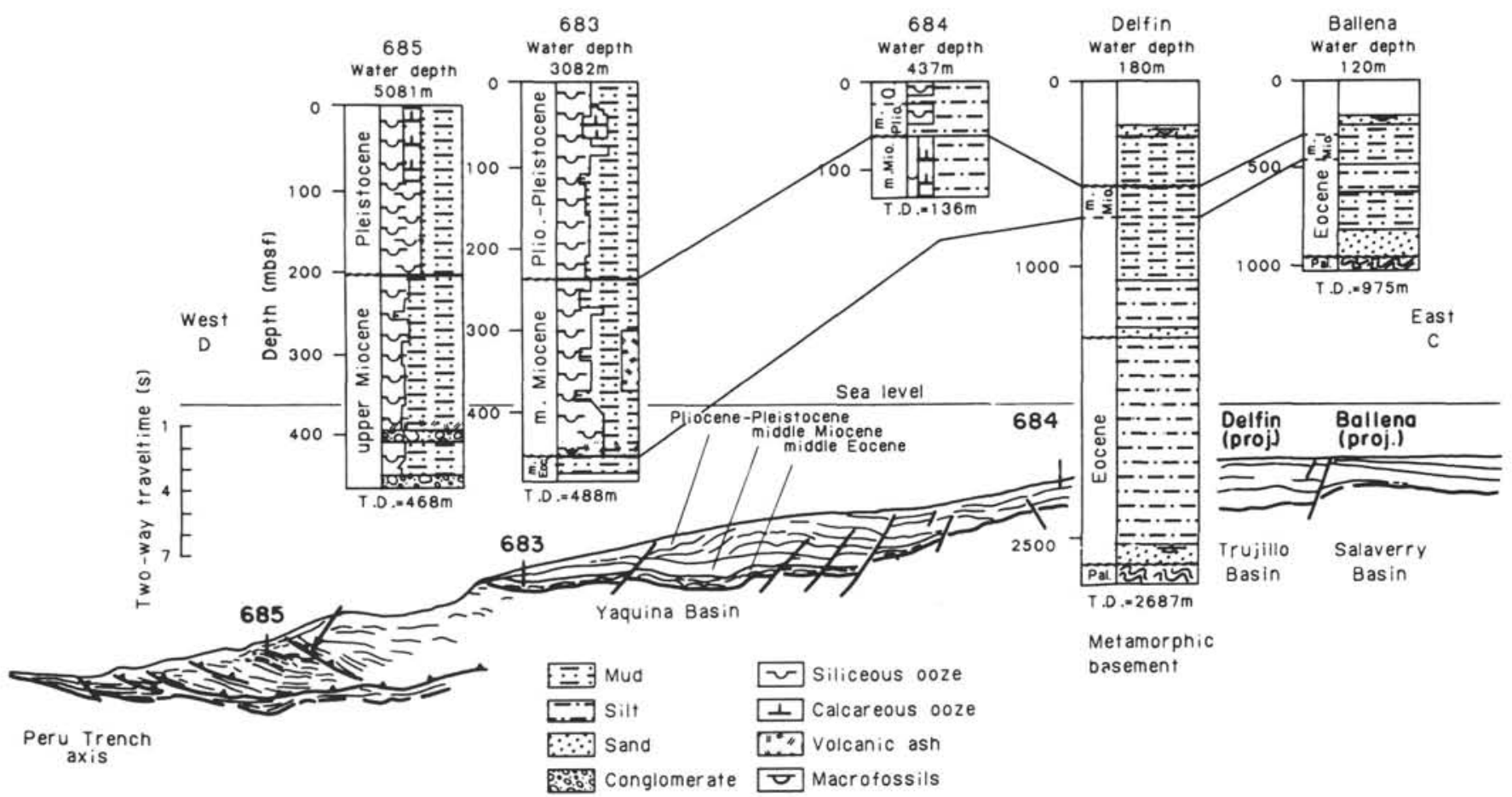

Figure 3. Simplified structural transect, based on seismic survey and results across the Peruvian margin at $9^{\circ} \mathrm{S}$. Included are results from industry holes, Ballena and Delfin. T.D. = total penetration depth.

Zone) and NR2 (C. tuberosa Zone). Thus, the upper part of Hole $683 \mathrm{~A}$, down to Sample 112-683A-5H-CC (40.2 mbsf) is late to middle Pleistocene in age.

The interval between Samples 112-683A-6H-CC (47.7 mbsf) and -22X-CC (201.7 mbsf) spans the middle Pleistocene to late Pliocene Zones NR3 to NR7 (S. universus Zone to A. jenghisi Zone). Zonal boundaries cannot be precisely determined because of the scarcity of almost all stratigraphic marker species. However, some rough age assignments, based on occurrences of rare species, may be proposed. Sample 112-683A-7H-CC (59.2 mbsf) can be referred to Zones NR3/NR4 (S. universus/A. ypsilon Zones), which are younger than $0.8 \mathrm{Ma}$ because of the presence of Pterocorys hertwigii (Johnson et al., in press). Co-occurrences of Anthocyrtidium angulare, $L$. nigriniae, $L$. neoheteroporos, and $P$. pitomorphus, in Sample 112-683A-11X-CC (97.2 mbsf) are indicative of the early Pleistocene Zone NR5 (A. angulare Zone). The stratigraphic range of $L$. nigriniae may be much longer here than in tropical areas (Johnson et al., in press). Both $L$. nigriniae and its ancestor, $L$. neoheteroporos, are present in sediments recovered from Samples 112-683A-10X-CC (87.7 mbsf) (top of L. neoheteroporos) to 112-683A-17X-CC (154.2 mbsf) (bottom of L. nigriniae). Co-occurrences of $T$. vetulum and $C$. davisiana in Sample 112-683A-19X-CC (173.2 mbsf) place this sample in the late Pliocene in age.

The last consistent occurrence of $S$. peregrina in Sample 112-683A-23X-CC (211.2 mbsf) suggests an early Pliocene age for this sample. The interval between Sample 112-683A$23 \mathrm{X}-\mathrm{CC}(211.2 \mathrm{mbsf})$ and $-25 \mathrm{X}-\mathrm{CC}(230.2 \mathrm{mbsf})$ is placed in Zones NR8/NR9 ( $S$. peregrina/P. fistula Zones) because many representatives of $L$. neoheteroporos, whose first appearance is located in Zone NR7 (A. jenghisi Zone) in tropical sediments (Johnson et al., in press) are present, along with many specimens of $P$. fistula, whose last occurrence marks the limit between Zones NR8 and NR9. The presence of $L$. daniellae in Samples 112-683A-24X-CC (220.7 mbsf) and -25X-CC (230.2 mbsf) correlates well with its occurrence in DSDP Site 586B material (Caulet, 1985). Episodic occurrences of rare tropical forms and apparently local variation of some stratigraphic ranges do not permit us a more detailed zonation of the Pliocene sequence in Hole 683A.

A dramatic change in radiolarian composition occurs in Sample 112-683A-26X-CC (239.7 mbsf). More than $50 \%$ of the species present in the upper samples disappear completely. Occurrences of Botryostrobus miralestensis, Diartus petterssoni, D. antepenultima, Didymocyrtis laticonus, and Stichocorys delmontensis place Samples 112-683A-26X-CC ( $239.7 \mathrm{mbsf})$ to $-29 \mathrm{X}-\mathrm{CC}$ ( $268.2 \mathrm{mbsf})$ in the $D$. antepenultima Zone (early late Miocene). The first occurrence of $D$. antepenultima is used to mark the lower limit of this zone.

In Samples 112-683A-29X-CC (268.2 mbsf) to -40X-CC ( $372.7 \mathrm{mbsf})$ and $-42 \mathrm{X}-\mathrm{CC}(390.7 \mathrm{mbsf})$ to $-45 \mathrm{X}-\mathrm{CC}(419.2$ mbsf) radiolarians are few to rare, and preservation is moderate. Sediments barren of radiolarians were recorded in Sample 112-683A-41X-CC (381.2 mbsf), and from Sample 112-683A$44 \mathrm{X}-\mathrm{CC}$ (409.7 mbsf) to the bottom of the hole. All of this interval (112-683A-29X-CC [268.2 mbsf] to bottom of the hole) is middle Miocene in age. However, the limit between the two middle Miocene radiolarian biozones is not easily recognized, mainly because $D$. petterssoni is so rare. Last occurrences of D. mammifera and L. parkerae are tentatively used to mark the top of the Dorcadospyris alata Zone between Samples 112-683A-39X-CC (363.2 mbsf) and -40X-CC (372.7 mbsf). The stratigraphic range of $S$. wolffii appears to be diachronous in this hole relative to previously published ranges (Sanfilippo et al., 1985).

Occurrences of radiolarian species in Hole 683A are recorded in Table 2 . Hole $683 \mathrm{~B}$ was located $320 \mathrm{~m}$ upslope from Hole $683 \mathrm{~A}$ and was washed down to allow for two overlapping cores. All core-catcher samples from this hole were studied for radiolarians, which are present in all samples. Their preservation is good in Miocene sediments, and poor to moderate in the Eocene interval. They are common to abundant in Miocene sediments, few to common in the Eocene. 


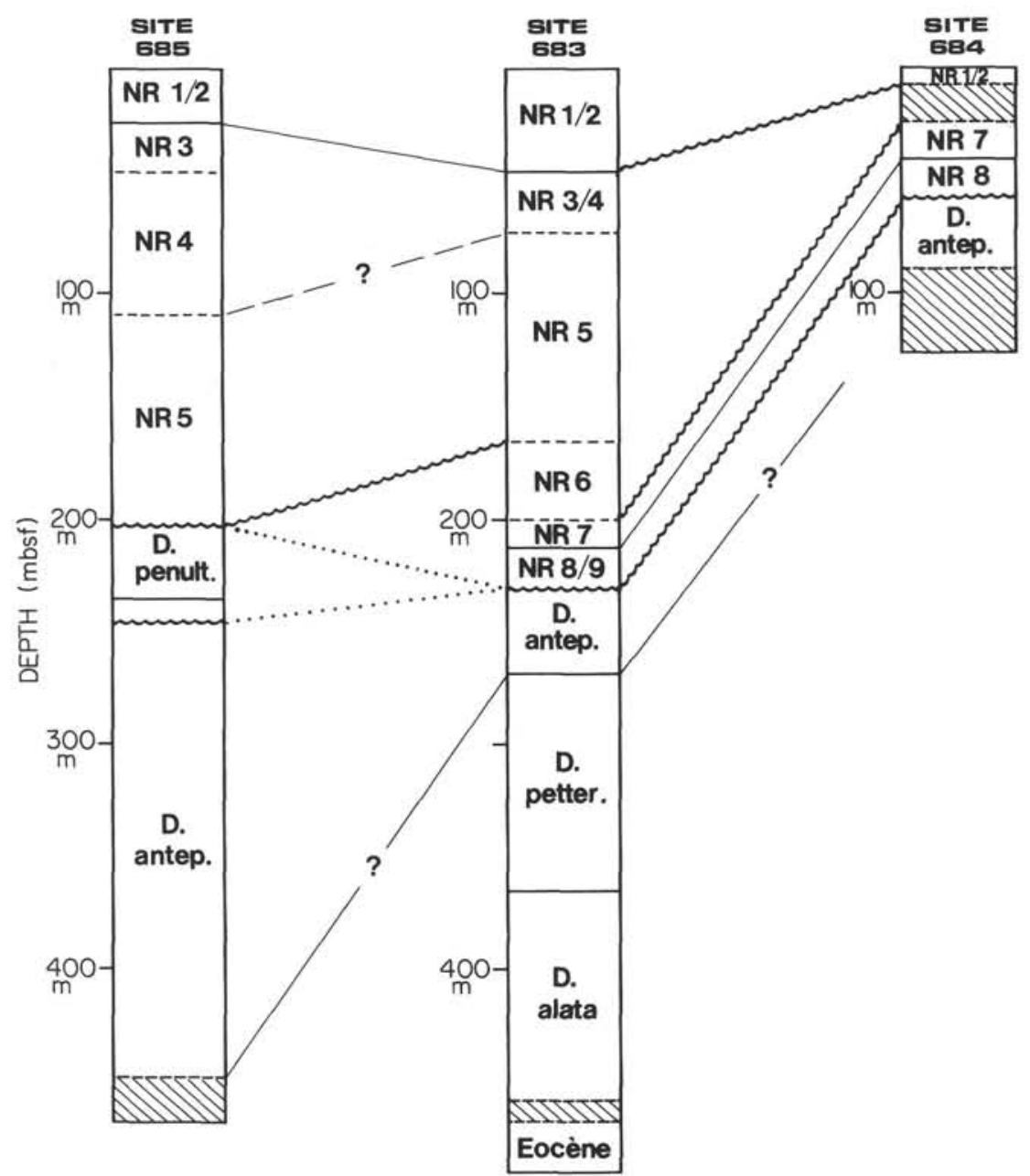

Figure 4. Summary of stratigraphic results based on radiolarians (northern transect, $9^{\circ} \mathrm{S}$ ).

A $D$. petterssoni Zone assemblage was observed in Samples $112-683 \mathrm{~B}-1 \mathrm{X}-\mathrm{CC}$ (412.0 mbsf) to - $6 \mathrm{X}-\mathrm{CC}$ (459.5 mbsf), indicating a middle Miocene age.

A strongly recrystallized assemblage of Eocene age (Eusyringium fistuligerum, Dictyoprora mongolfieri, and Podocyrtis papalis) was found in Samples 112-683B-7X-CC (469.0 mbsf) to $-9 \mathrm{X}-\mathrm{CC}$ (488.0 mbsf).

In Site 683 , two hiatuses can be deduced from the radiolarian stratigraphy. The first is located between Samples 112-683A-25X-CC (230.2 mbsf) and -26X-CC (239.7 mbsf), and spans the upper part of the late Miocene. The Miocene/ Pliocene boundary cannot be recognized. The second hiatus is located between Samples 112-683B-6X-CC (459.5 mbsf) and $-7 \mathrm{X}-\mathrm{CC}(469.0 \mathrm{mbsf})$. The early Miocene and all of the Oligocene is missing.

\section{Site 684}

Site $684\left(8^{\circ} 59.49^{\prime} \mathrm{S}, 79^{\circ} 54.35^{\prime} \mathrm{W}\right)$ is located in a small sediment pond on the flank of the Trujillo Basin, in an area on the upper slope otherwise devoid of sediments. It represents the northern point of a transect along the Peruvian coastal upwelling regime.

The sediments at Site 684 , compared with previously drilled sites along the transect, record the latitudinal variability of the upwelling (Site 684, part A). Radiolarians are rare to abundant in all three holes drilled at Site 684 . Their preserva- tion is generally excellent, except in organic-rich pyritic mud intervals.

All core-catcher samples from Hole 684A were studied for radiolarians. They are well preserved, but are generally rare to few, because of dilution by diatoms, except in Sample 112$684 \mathrm{~A}-5 \mathrm{H}-\mathrm{CC}$ ( $43.3 \mathrm{mbsf})$ where they are common. An assemblage of the Peru margin Holocene (Plectacantha cresmatoplegma, D. infabricatus) was found in Sample 112$684 \mathrm{~A}-1 \mathrm{H}-\mathrm{CC}$ ( $5.3 \mathrm{mbsf}$ ). Rare radiolarians of Quaternary age were observed in Sample 112-684A-2H-CC (14.8 mbsf), but no assignment to a radiolarian biozone can be proposed. A major hiatus (late Pliocene) seems to be located between Samples 112-684A-2H-CC (14.8 mbsf) and -3H-CC (24.3 mbsf). Samples 112-684A-3H-CC (24.3 mbsf) and -4H-CC (33.8 mbsf) are placed in the middle Pliocene Zone NR7 ( $A$. jenghisi Zone). These samples contain many specimens of $T$. vetulum, rare $A$.jenghisi, and no $C$. davisiana. It is interesting to note the relative abundance of the rare species $L$. daniellae at these levels. The occurrence of $S$. peregrina, and the absence of $L$. neoheteroporos place Sample 112-684A-5H-CC (43.3 mbsf) in Zone NR8 ( $S$. peregrina Zone). Sample 112$684 \mathrm{~A}-6 \mathrm{H}-\mathrm{CC}$ ( $52.8 \mathrm{mbsf})$ is barren of radiolarians. Rare, but well-preserved, bispecific assemblages of $D$. antepenultima and $D$. hughesi give an early late Miocene age (D. antepenultima Zone) to the interval between Sample 112-684A-7H-CC (62.3 mbsf) and -10X-CC (88.6 mbsf). Because Sample 112- 

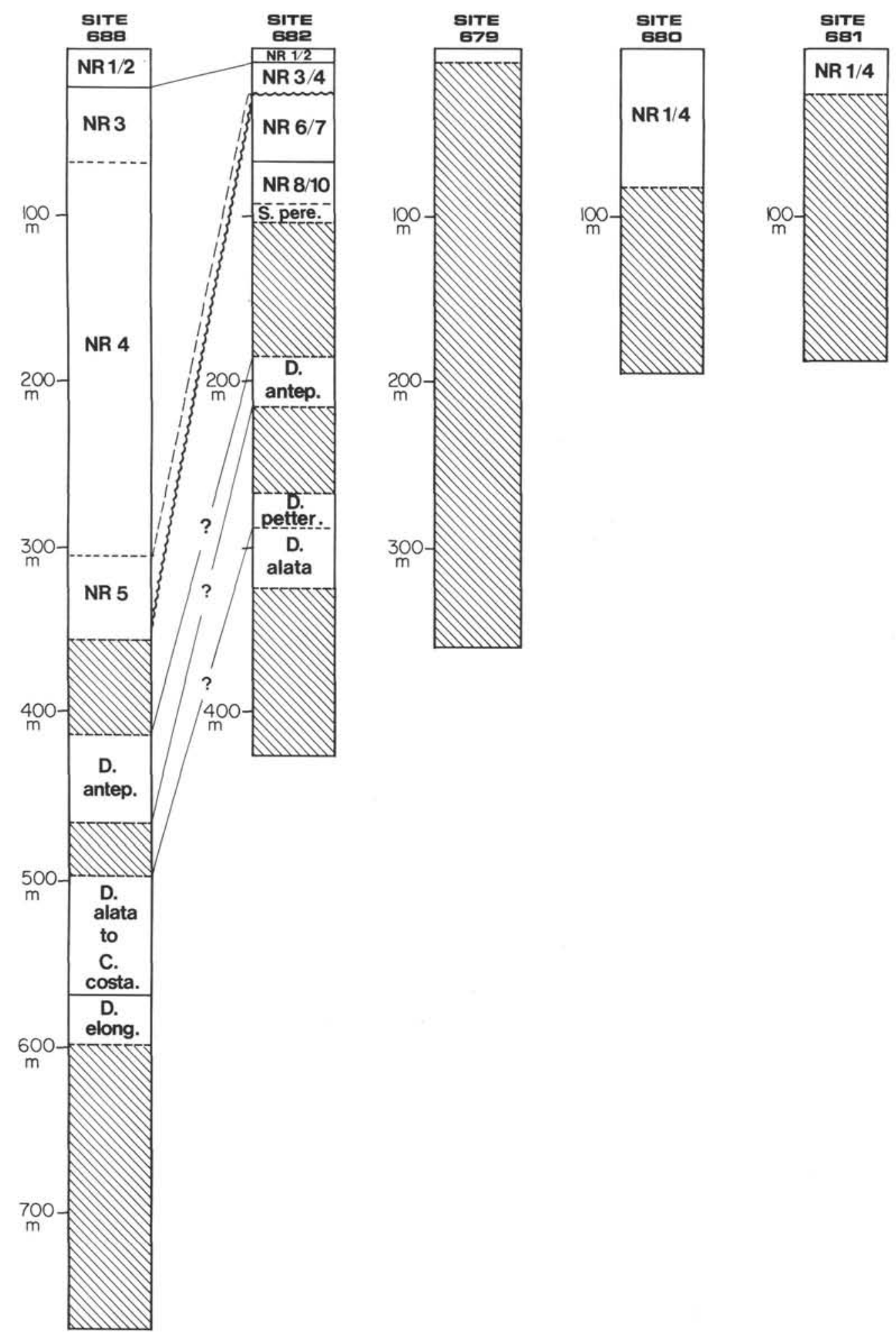

Figure 5. Summary of stratigraphic results based on radiolarians (southern transect, $11^{\circ} 30^{\prime} \mathrm{S}$ ).

$684 \mathrm{~A}-6 \mathrm{H}-\mathrm{CC}(52.8 \mathrm{mbsf})$ is barren, no direct evidence exists for a hiatus spanning the upper part of the late Miocene, but it seems likely that Sample 112-684A-11X-CC (98.1 mbsf) is barren.

Transitional forms between $D$. antepenultima and $D$. laticonus were observed in Sample 112-684A-12X-CC (107.6 mbsf). However, no age assignment can be proposed because radiolarians are too rare in this sample, as well as downhole.

Radiolarians are well preserved, but rare to few, in all core-catcher samples from Hole 684C. Samples 112-684C$1 \mathrm{H}-\mathrm{CC}(7.8 \mathrm{mbsf})$ and $-2 \mathrm{H}-\mathrm{CC}(17.3 \mathrm{mbsf})$ contain a Quaternary assemblage. Sample $112-684 \mathrm{C}-3 \mathrm{H}-\mathrm{CC}$ ( $26.8 \mathrm{mbsf})$ can be 
related to the middle Pliocene Zone NR7 (A. jenghisi Zone). L. daniellae is abundant. Samples $112-684 \mathrm{C}-4 \mathrm{H}-\mathrm{CC}(36.3$ mbsf) to $-6 \mathrm{X}-\mathrm{CC}$ ( $48.5 \mathrm{mbsf})$ are assigned to Zone NR8 ( $S$. peregrina Zone). Sample 112-684C-7X-CC (58.0 mbsf) is barren of radiolarians. The interval between Samples 112$684 \mathrm{C}-8 \mathrm{X}-\mathrm{CC}$ ( $67.5 \mathrm{mbsf})$ and $-10 \mathrm{X}-\mathrm{CC}(86.5 \mathrm{mbsf})$ belongs to the $D$. antepenultima Zone. Below this interval, and following the same sequence as in Hole 684A, a barren sample and rare late to middle Miocene forms were successively observed.

\section{Site 685}

Site $685\left(9^{\circ} 06.78^{\prime} \mathrm{S}, 80^{\circ} 35.01^{\prime} \mathrm{W}\right)$ is located on the lower slope of the Peru Trench, at a depth of $5070 \mathrm{~m}$, about $1200 \mathrm{~m}$ above the trench floor. The stratigraphy and fabric of the cored section are consistent with the accretionary nature apparent in the seismic record. The change from upper Miocene nonaccretionary to accretionary sediments along the Peru Trench occurs after the Nazca Ridge was subducted at the latitude of the site. At the same time, sedimentation increased dramatically following the onset of coastal upwelling. Hole $685 \mathrm{~A}$ was drilled to a depth of $459.1 \mathrm{mbsf}$ into the lower slope sediment prism.

All core-catcher samples from Hole $685 \mathrm{~A}$ have been studied for radiolarians. They are well preserved and abundant to common in Samples 112-685A-1H-CC (4.1 mbsf) to $-23 \mathrm{X}-\mathrm{CC}$ (213.1 mbsf). Downhole, they are generally few to rare and moderately to poorly preserved. Samples 112$685 \mathrm{~A}-47 \mathrm{X}-\mathrm{CC}$ (430.6 mbsf) to $-51 \mathrm{X}-\mathrm{CC}$ (468.1 mbsf) are almost barren. The techniques used for Mesozoic rocks (De Wever et al., 1979; De Wever, 1982) were employed to extract radiolarians from Samples 112-685A-39X-CC to -51X-CC (357.1-468.1 mbsf).

The last appearance of $S$. universus in Sample 112-685A4H-CC (32.6 mbsf) marks the lower limit of Zones NR1/NR2 (B. invaginata/C. tuberosa Zones). Last appearances of $A$. nosicaae and $P$. pitomorphus in Sample 112-685A-6X-CC (51.6 mbsf) place the lower limit of Zone NR3 $(S$. universus Zone) above this sample. The interval from this boundary to the first appearance of L. nigriniae in Sample 112-685A21X-CC (194.1 mbsf) has not been divided; it spans the middle and early Pleistocene Zones NR4/NR5 (A. ypsilon/A. angulare Zones). Many Miocene species, like D. antepenultima, Didymocyrtis penultima, and $S$. peregrina, were observed in Sample 112-685A-22X-CC (203.6 mbsf). It is not clear if this sample is of Pleistocene or Miocene age, since the sample may be either contaminated or contain reworked fauna. This uncertainty is probably related to a hiatus. Sample 112$685 \mathrm{~A}-23 \mathrm{X}-\mathrm{CC}$ (213.1 mbsf) can be assigned to the late Miocene $D$. penultima Zone. The occurrences of many reworked specimens, such as D. petterssoni and Cyrtocapsella elongata, and specimens originating from the sub-Antarctic, such as Prunopyle hayesi, as well as two barren samples, are indicative of strong currents and reworking patterns during the late Miocene. The lower limit of this interval has been tentatively placed at the first appearance of $D$. penultima in Sample 112-685A-26X-CC (233.6 mbsf). Radiolarian assemblages found downhole include many species characteristic of the early late Miocene $D$. antepenultima Zone markers: $D$. antepenultima, $D$. hughesi and $S$. delmontensis. The transitions between $D$. petterssoni and $D$. hughesi and between $D$. laticonus and D. antepenultima are unclear. In the former case, the transition appears to be prolonged between Samples 112-685A-45X-CC (411.6 mbsf) and -49X-CC (449.6 mbsf), while in the latter case no specimens of D. laticonus were observed; hence, no lower limit is proposed herein for the $D$. antepenultima Zone. Samples 112-685A-43X-CC (392.6 mbsf) and $-44 \mathrm{X}-\mathrm{CC}$ (402.1 mbsf) contain reworked species of
Eocene/Oligocene age (Dorcadospyris ateuchus, Eusyringium fistuligerum and Lithocyclia aristotelis). Occurrences of radiolarians in Hole $685 \mathrm{~A}$ are recorded in Table 3.

\section{Site 686}

Site $686\left(13^{\circ} 28.81^{\prime} \mathrm{S}, 76^{\circ} 53.49^{\prime} \mathrm{W}\right)$ is located in the West Pisco Basin. It represents the southernmost point of the north-south transect designed to study paleoceanography along the outer Peru shelf. The drilling area is adjacent to exposures on land of the famous Miocene Pisco Formation, a classic association of diatomites, cherts, and dolomites, thought to have formed under coastal upwelling conditions (Muizon and Bellon, 1980). Two holes were drilled at Site 686 in a water depth of $447 \mathrm{~m}$ to recover sediments deposited under upwelling conditions during the late Neogene and Quaternary age. Drilling at Hole 686A penetrated $205.7 \mathrm{~m}$, and at Hole 686B, $303 \mathrm{~m}$, of Quaternary sediments. The base of the Quaternary was not reached.

All core-catcher samples from Hole 686A were studied for radiolarians. They are generally rare, but well to moderately preserved in all samples.

A Quaternary radiolarian assemblage, including $L$. nigriniae, was found in Samples 112-686A-2H-CC (14.6 mbsf), -5H-CC (43.1 mbsf), -9X-CC (72.7 mbsf), -12X-CC (101.2 mbsf), and $-13 X-C C$ (110.7 mbsf). Other samples in this interval are barren.

\section{Site 687}

Site $687\left(12^{\circ} 51.78^{\prime} \mathrm{S}, 76^{\circ} 59.43^{\prime} \mathrm{W}\right)$ is located on the seaward flank of the tectonically stable Lima Platform, which forms the eastern and southern boundaries of the Lima Basin in this area. Two holes were drilled at Site 687 to recover upper-slope sediments deposited under upwelling conditions during the late Neogene and Quaternary. Drilling at Hole 687A penetrated $202.00 \mathrm{~m}$ and at Hole $687 \mathrm{~B}, 185.80 \mathrm{~m}$ of Quaternary and Pliocene sediments. The base of the Quaternary was reached at $127.92 \mathrm{~m}$ in Hole $687 \mathrm{~A}$ and at $110.22 \mathrm{~m}$ in Hole $687 \mathrm{~B}$. All core-catcher samples from Hole $687 \mathrm{~A}$ were studied for radiolarians. They are rare in all samples, but preservation is good to moderate.

The usual Quaternary radiolarian assemblage with $L$. nigriniae was found in Samples 112-686A-1H-CC (5.1 mbsf) and -14X-CC (120.2 mbsf). Samples 112-687A-6H-CC (52.6 mbsf) to -7X-CC (62.1 mbsf), Samples 112-687A-10X-CC (82.1 mbsf) to $-15 X-C C$ (129.7 mbsf), and Samples 112-687A-17XCC (148.7 mbsf) to $-19 \mathrm{X}-\mathrm{CC}$ (167.7 mbsf) did not yield sufficient radiolarians to allow us to determine ages. Samples $112-687 \mathrm{~A}-2 \mathrm{H}-\mathrm{CC}$ (14.6 mbsf) to $-5 \mathrm{H}-\mathrm{CC}$ (43.1 mbsf), and 112-687A-8X-CC (64.7 mbsf), -20X-CC (177.2 mbsf), and -22X-CC (196.2 mbsf) are barren. Samples 112-687A-11X-CC (62.1 mbsf) to $-13 \mathrm{X}-\mathrm{CC}(1110.7 \mathrm{mbsf})$ and $-16 \mathrm{X}-\mathrm{CC}(139.2$ $\mathrm{mbsf}$ ) were unavailable for radiolarian investigations. Sample 112-687A-10X-CC (82.2 mbsf) contains Didymocyrtis tubarius, which is indicative of an early Miocene age and is probably reworked.

\section{Site 688}

Site $688\left(11^{\circ} 32.26^{\prime} \mathrm{S}, 78^{\circ} 56.57^{\prime} \mathrm{W}\right)$ is on the lower slope of the Peru Trench about $30 \mathrm{~km}$ landward of the trench axis. The site is located about $32 \mathrm{~km}$ south-southeast from Site 682 , parallel to the regional trend. Five holes were drilled in a water depth of $3820 \mathrm{~m}$ at Site 688 , but cores were recovered from only three holes (688A, 688C and 688E). Drilling in Hole $688 \mathrm{~A}$ penetrated $350.3 \mathrm{~m}$ of mostly Quaternary hemipelagic sediments. The lowermost sample at $343.4 \mathrm{mbsf}$ may be late Pliocene in age. One core of Quaternary diatomaceous mud was recovered at $359.8 \mathrm{mbsf}$ in Hole $688 \mathrm{C}$. Drilling at Hole $688 \mathrm{E}$ penetrated $779 \mathrm{~m}$ of Quaternary to Eocene sediments. 
Techniques used for shales and Mesozoic rocks were employed to extract radiolarians from Sample 112-688E16R-CC (498.0 mbsf), and the remaining downhole samples.

Radiolarians were studied in all core-catcher samples from Hole $688 \mathrm{~A}$. They are common to abundant, and generally well preserved in all samples. The last appearance of $S$. universus in Sample 112-688A-4H-CC (36.8 mbsf) marks the top of Zone NR3 ( $S$. universus Zone). The interval between the top of the hole and this sample is placed in the late Pleistocene Zones NR1/NR2 (B. invaginata/C. tuberosa Zones). The lower limit of Zone NR3 ( $S$. universus Zone) cannot be determined because the first occurrence of Collosphaera tuberosa was not recognized. A single occurrence of this species was observed in Sample 112-688A-3H-CC (27.3 mbsf). The last occurrence of A. nosicaae, ( 0.6 to $0.7 \mathrm{Ma}$ in tropical areas; Johnson et al., in press), in Sample 112-688A-8X-CC (74.8 mbsf), is indicative of Zone NR4 (A. ypsilon Zone). The lower limit of Zone NR4 cannot be determined because only one occurrence in Sample 112-688A-34X-CC (321.8 mbsf) of $A$. angulare was observed. Co-occurrence of $L$. nigriniae in the same sample is indicative of the early Pleistocene Zone NR5 (A. angulare Zone). Rare radiolarian species of early Pliocene age $(S$. peregrina, $A$. pliocenica, and $P$. vema) are reworked in Samples 112-688A-34X-CC (321.8 mbsf) and -35X-CC (331.3 mbsf). The Pliocene/Pleistocene boundary was not recognized. Occurrences of radiolarian species in Hole 688A are recorded in Table 4.

All core-catcher samples from Hole $688 \mathrm{E}$ were studied for radiolarians. They are rare, except in Sample 112688E-1R-CC (355.5 mbsf), which contains few radiolarians. Preservation is generally poor. Sample 112-688E-1R-CC (355.5 mbsf) is probably of early Pleistocenen age as it contains $L$. neoheteroporos. Samples 112-688E-2R-CC (365.0 mbsf) to -7R-CC (412.5 mbsf) are poor in radiolarians. Rare specimens of $D$. hughesi, $C$. tetrapera, $S$. delmontensis, P. fistula, and Eucyrtidium cienkowskii are indicative of an early late Miocene age for Sample 112-688E-8R-CC (422.0 mbsf). Radiolarians are very rare and moderately preserved in Samples 112-688E-10R-CC (441.0 mbsf) to -12R-CC (460.0 mbsf). Occurrence of $D$. antepenultima in these samples is indicative of the D. antepenultima Zone (early late Miocene). Samples 112-688E-13R-CC (469.5 mbsf) to -16R-CC (498.0 mbsf) are barren of radiolarians. Well-preserved specimens of $C$. tetrapera, $S$. delmontensis, E. cienkowskii, L. parkerae, and Calocycletta robusta are common in Sample 112-688E-19R-CC (526.5 mbsf). This level is tentatively referred to the $D$. alata Zone (early middle Miocene). In Sample 112-688E-19R-CC (526.5 mbsf), well preserved and abundant radiolarians are indicative of an early $D$. alata Zone to a late $C$. costata Zone interval (late early Miocene to early middle Miocene): D. mammifera, $D$. tubarius, and no D. laticonus, Dendrospyris bursa, Calocycletta virginis, or L. parkerae. One reworked specimen of Lychnocanoma elongata, common in the early Miocene, was observed. The same fauna was observed down to Sample 112-688E-23R-CC (564.5 mbsf). In Samples 112688E-25R-CC (583.5 mbsf) and -26R-CC (593.0 mbsf), wellpreserved and common specimens of Centrobotrys petrushevskayae, C. tetrapera, Didymocyrtis prismaticus, Histiastrum martinianum, L. elongata, Tessarospyris pododendros, and Theocyrtis tuberosa place this interval in the early Miocene ( $L$. elongata to $C$. tetrapera Zones). No direct evidence exists for a hiatus between the late and early Miocene, but sedimentation rates were probably low during the early Miocene in this area. Downhole, radiolarians are generally absent or rare and are strongly recrystallized. No age assignment can be proposed for the interval.

\section{SUMMARY}

\section{Stratigraphy}

Stratigraphic results are summarized in Figures 2 and 3. Pleistocene radiolarian assemblages are generally well preserved in almost all sites. However, most traditional stratigraphic markers are missing and only one precisely dated event was observed: the last occurrence of $S$. universus $(0.4$ Ma; Morley and Shackleton, 1976), which marks the boundary between Zones NR2 and NR3 (C. tuberosa and $S$. universus Zones). This event was recognized in all sites, except the shallow ones (Sites $679,680,681$ ). Other definitive Pleistocene zonal markers, between Zones NR1 and NR2 (FAD of $B$. invaginata), between Zones NR3 and NR4 (FAD of $C$. tuberosa) and between Zones NR4 and NR5 (LAD of $A$. angulare), were not recognized. Some events were tentatively used to indicate biozones, even though no absolute ages were available for this material. The LAD of $A$. nosicaae and of $P$. pitomorphus lie within Zone NR4. The FAD of $L$. nigriniae may be diachronous and older than in tropical sediments. It has been found, herein, to occur in the lower part of Zone N5, whereas in tropical sediments (Johnson et al., in press), it occurs in the upper part of Zone NR5.

Because of hiatuses and/or barren intervals, the Pliocene/ Pleistocene boundary (NR5/NR6) was recognized only in Site 683. In Site 683, a late Pliocene age was surmised for Sample 112-683A-19X-CC (173.2 mbsf) on the basis of the co-occurrence of $L$. neoheteroporos, $C$. davisiana, and $T$. vetulum. However, the NR5/NR6 boundary is not precise because no specimens of Pterocanium prismatium were found. The boundary between NR7 and NR8 (LAD of $S$. peregrina; 2.6 to $2.7 \mathrm{Ma}$ in Johnson et al., in press) was recognized in Sites 682, 683, and 684. The $S$. peregrina Zone, which spans the late Miocene and early Pliocene, was recognized only in Sample 112-682A-8X-CC (76.3 mbsf), based on a rare co-occurrence of Pseudocubus vema (an early sub-Antarctic and Mediterranean Pliocene species), $S$. peregrina, and $L$. daniellae, whose stratigraphical range is short and typical of the early Pliocene part of the $S$. peregrillna Zone (Caulet, 1985).

The upper part of the late Miocene was not recognized using the radiolarian data in Leg 112 material. Thus, the Miocene/Pliocene boundary could not be defined. Assemblages referred to the $D$. penultima Zone were only observed in Site 685. D. penultima specimens are well preserved, and there is no doubt about their identification. However, reworked skeletons are abundant in the same samples, and deposition of this rarely found (in this area) late Miocene interval was probably influenced by strong hydrodynamic patterns. Radiolarian assemblages belonging to the early late Miocene $D$. antepenultima Zone are common in all sites, but the transition from $D$. antepenultima to $D$. penultima was observed only in Site 685 . The lower limit of this zone (transition between $D$. petterssoni and D. hughesi, and transition between $D$. laticonus and $D$. antepenultima) was observed only in Site 683. In Sites 682, 684, 685, and 688, there are barren intervals at the base of the $D$. antepenultima Zone.

Middle Miocene assemblages are poorly preserved in Sites 682 and 688 . Better preservation in Site 685 permitted definition of the boundary between the $D$. petterssoni and $D$. alata Zones. The first appearance of $D$. petterssoni is not clear in Site 682 , but assemblages representative of the two zones were observed.

Late early Miocene assemblages can be found only in Site 688. Due to many barren samples, and poor preservation, a precise biozonation of this period cannot be proposed. The $C$. costata and $D$. elongata Zones are probably represented in 
Site 688 , but their limits, as well as the middle/early Miocene boundary, were not recognized.

Eocene radiolarians are so crystallized in Site 683, that no biozonation can be proposed.

\section{Radiolarian Events}

As no absolute ages and no continuous sequences are available in Leg 112 material, only relative ranges of some species can be discussed. Using the last occurrences of $S$. universus and $A$. nosicaae, the first appearances of some species described by Nigrini (1968) in Holocene sediments from the eastern tropical Pacific, can be tentatively dated: (1) Cypassis irregularis is restricted to Zones NR1/NR2; (2) the first occurrence of $P$. cresmatoplegma is tentatively placed below the NR3/NR4 zonal boundary; (3) D. infabricatus evolves just below the LAD of $A$. nosicaae in Zone NR4; (4) specimens of $P$. grandiporus are rare, but first appearances of the species in Sites 683,685 , and 688 , are diachronous (NR4 to NR2). This latter event seems, however, to be unreliable because the species may not be sufficiently well defined (Lazarus, 1985).

The species $P$.(?) crustula, described by Caulet, 1979, from the central Indian Ocean, is abundant in our material. We do not know if this species is extant. Its last common occurrence is located in sediments younger than $0.4 \mathrm{Ma}$. Observations of its FAD are not conclusive because the earliest specimens occur in the early Pliocene of Site 683, but in early Miocene samples (D. antepenultima Zone) from Site 685 . However, the D. antepenultima interval may be incomplete in Site 685 . More observations are needed to clarify these results. Many specimens of $L$. daniellae, described in early Pliocene sediments from the southwest Pacific (Caulet, 1985) were found in early Pliocene levels in Leg 112 material. Unfortunately, early Pliocene sediments are rare, and a continuous sequence from Miocene to Pleistocene was not recorded. Thus, new data for the stratigraphic range of this species are not available. However, it is interesting to note that specimens of $L$. daniellae occur in the same samples as the first $L$. neoheteroporos in Sites 682 and 683 . More studies will be necessary to decide if patterns of evolution in the $L$. heteroporos $-L$. nigriniae lineage should be changed so as to include $L$. daniellae.

Among the species described by Goll (1980), P. warreni was abundant in Leg 112 material. The first occurrence of this form was recorded in the early Pliocene samples from Sites 682 and 683. In Site 682, co-occurrences of $P$. vema and $P$. warreni could be indicative of a new lineage, but more observations will be necessary before $P$. vema can be confirmed as the ancestor of $P$. warreni. Phylogenetic relationships in the A. murrayanalA trepanatalA. cyrtodon group are not so clear as those described by Goll, probably because the forms may not be well understood, or are, in fact, conspecific.

New observations about Eucyrtidium infundibulum, a form described by Haeckel, 1887, as Lithomitra infundibulum, but since forgotten, show that this species might be used for stratigraphy. Its last appearance was recorded in Zone NR1/ NR2, but no specimens were found in the most recent sediments. Early representatives of the species are common in early Pliocene sediments of Sites 682 and 683 . Rarely, similar forms were observed in the $D$. penultima interval of Site 685 . More accurate observations concerning the first occurrence of this species are not available from our material.

\section{ACKNOWLEDGMENTS}

Financial support for this study was provided by ODP-France Grant 950151 and by CNRS-ASP-INSU Grant 6374 . We would like to thank C. Nigrini for many helpful discussions about the eastern Pacific species and for revising the paper into a very good English. Many thanks are also due to D. W. Murray for numerous good suggestions.

\section{REFERENCES}

Bailey, J. W., 1856. Notice of microscopic forms found in the soundings of the Sea of Kamtschatka-with a plate. Am. J. Sci. Arts, Ser. 2, 22:1-6.

Björklund, K. R., 1977. Actinomma haysi, n.sp., its Holocene distribution and size variation in Atlantic Ocean sediments. Micropaleontology, 23:114-126.

Björklund, K. R., and Goll, R. M., 1979. Internal skeletal structures of Collosphaera and Trisolenia: a case of repetitive evolution in the Collosphaeridae (Radiolaria). J. Paleontol., 53:1293-1326.

Campbell, A. S. and Clark, B. L., 1944. Miocene radiolarian faunas from southern California. Geol. Soc. Am., Spec. Pap., 51:1-76.

Carnevale, P., 1908. Radiolarie e silicoflagellati di Bergonzano (Reggio Emilia). Mem. R. Istit. Sci., Lett. Arti, 28:1-46.

Caulet, J., 1971. Contribution à l'étude de quelques Radiolaires Nassellaires des boues de la Méditerranée et du Pacifique. Cahiers Micropaléontol., Série 2, No. 10, Archives originales, Centre de Documentation C.N.R.S., 498:1-10. , 1979. Les dépots à radiolaires d'âge Pliocène supérieur à Pleistocène dans l'océan Indien central: nouvelle zonation biostratigraphique. Mém. Museum Nat. Hist. Nat., 43(C):119-141. , 1985. Radiolarians from the Southwest Pacific. In Kennett, J. P., von der Borch, C. C., et al., Init. Repts. DSDP, 90: Washington (U.S. Govt. Printing Office), 835-861.

1986. A refined radiolarian biostratigraphy for the Pleistocene of the temperate Indian Ocean. Mar. Micropaleontol., 11:217-229.

Chen, P. H., 1975. Antarctic Radiolaria. In Hayes, D. E., Frakes, L. A., et al., Init. Repts. DSDP, 28: Washington (U.S. Govt Printing Office), 437-513.

Clark, B. L., and Campbell, A. S., 1942. Eocene radiolarian faunas from the Monte Diablo area, California. Geol. Soc. Am. Spec. Pap., 39:1-112.

De Wever, P., 1982. Radiolaires du Trias et du Lias de la Téthys (Systématique, Stratigraphie). Mem. Soc. Geol. Nord, 7:1-599.

De Wever, P., Riedel, W., Baumgartner, P., Dumitrica, P., Björklund, K., Caulet, J. P., Drobne, K., Grandlund, A., Kocher, R., and Schaaf, A., 1979. Eurorad '78: Recherches actuelles sur les Radiolaires en Europe. Аnпи. Soc. Geol. Nord, Lille, XCVIII:205-222.

Dogel, V. A., and Reshetnyak, V. V., 1952. Materialy po radiolyariyam severozapadnoi chasti tikhogo okeana (Material on radiolarians of the northwestern part of the Pacific Ocean). Issledov. Dalnevost. Morei SSSR, 3:5-36.

Dreyer, F., 1889. Die Pylombildungen in vergleichend-anatomischer und entwicklungsgeschichtlicher Beziehung bei Radiolarien und bei Protisten uberhaupt. Jenais. Zeits. Naturwiss., 23:1-138.

Dumitrica, P., 1973. Cretaceous and Quaternary Radiolaria in deep sea sediments from the northeast Atlantic Ocean and Mediterranean Sea. In Ryan, W.B.F., Hsu, K. J., et al., Init. Repts. DSDP, 13(Pt. 2): Washington (U. S. Govt. Printing Office), 829-901.

Ehrenberg, C. G., 1838. Uber die Bildung der Kreidefelsen und des Kreidemergels durch unsichtbare Organismen. Konig. Akad. Wissen. Berlin, Abhandlungen, Jahre 1838:59-147.

, 1844. Uber 2 neue Lager von Gebirgsmassen aus Infusorien als Meeres-Absatz in Nord-Amerika und eine Vergleichung derselben mit den organischen Kreide-Gebilden in Europa und Afrika. Konig. Preuss. Akad. Wissen. Berlin, Bericht, Jahre 1844:57-97.

1847. Uber die mikroskopischen kieselschaligen Polycystinen als machtige Gebirgsmasse von Barbados und uber das Verhaltniss der aus mehr als 300 neuen Arten bestehenden ganz eigenthumlichen Formengruppe jener Felsmasse zu den jetzt lebenden Thieren undzur Kreidebildung Eine neue Anregung zur Erforschung des Erdlebens. Konig. Preuss. Akad. Wissen. Berlin, Bericht, Jahre 1847:40-60.

1854a. Die systematische Charakteristik der neuen mikroskopischen Organismen des tiefen atlantischen Oceans. Konig. Preuss. Akad. Wissen. Berlin, Bericht, Jahre 1854:236-250. 1854b. Mikrogeologie: Leipzig (Voss) Vol. xxviii plus Atlas, Fortsetzung (1856). 
1860a. Uber die organischen und unorganischen Mischungsverhaltnisse des Meeresgrundes in 19,800 Fuss Tiefe nach Lieut. Brookes Messung. Konig. Preuss. Akad. Wissen. Berlin, Monat. Jahre, 1860:765-774.

1860b. Uber den Tiefgrund des stillen Oceans zwischen Californien und den Sandwich-Inseln aus bis 15600 'Tiefe nach Lieutenant Brooke. Konig. Preuss. Akad. Wissen. Berlin, Monat. Jahre, 1860:819-833.

1861. Uber die Tiefgrund-Verhaltnisse des Oceans am Einegange der Davisstrasse und bei Island. Konig. Preuss. Akad. Wissen. Berlin, Monat. Jahre, 1861:275-315.

1872a. Mikrogeologische Studien als Zusammenfassung der Beobachtungen des kleinsten Lebens der Meeres-Tiefgrunde aller Zonen und dessen geologischen Einfluss. Konig. Preuss. Akad. Wissen. Berlin, Monat. Jahre, 1872:265-322.

$1872 \mathrm{~b}$. Mikrogeologische Studien uber das kleinste Leben der Meeres-Tiefgrunde aller Zonen und dessen geologischen Einfluss. Konig. Preusse. Akad. Wissen. Berlin, Abhand., Jahre, 1872:131-139.

1873. Grossere Felsproben des Polycystinen-Mergels von Barbados mit weiteren Erlauterungen. Konig. Preuss. Akad. Wissen. Berlin, Monat. Jahre, 1873:213-263.

1875. Fortsetzung der mikrogeologischen Studien als Gesammt-Uebersicht der mikroskopischen Palaontologie gleichartig analysirter Gebirgsarten der Erde, mit specieller Rucksicht auf den Polycystinen-Mergel von Barbados. Konig. Preuss. Akad. Wissen. Berlin, Abh. Jahre, 1875:1-225.

Foreman, H. P., 1973. Radiolaria of Leg 10 with systematics and ranges for the families Amphipyndacidae, Artostrobiidae, and Theoperidae. In Worzel, J. L. and Bryant, W. et al., Init. Repts. DSDP, 10: Washington (U.S. Govt. Printing Office), 407-474.

Goll, R. M., 1968. Classification and phylogeny of Cenozoic Trissocyclidae (Radiolaria) in the Pacific and Caribbean Basins. Part I. J. Paleontol., 42:1409-1432.

1969. Classification and phylogeny of Cenozoic Trissocyclidae (Radiolaria) in the Pacific and Caribbean basins. Part II. $J$. Paleontol., 43:322-339.

1976. Morphological intergradation between modern populations of Lophospyris and Phormospyris (Trissocyclidae, Radiolaria). Micropaleontology, 22:379-418.

1980. Pliocene-Pleistocene Radiolaria from the East Pacific Rise and the Galapagos spreading center, Deep Sea Drilling Project Leg 54. In Rosendahl, B. R., Hekinian, R., et al., Init. Repts. DSDP, 54: Washington (U. S. Govt. Printing Office), 425-454.

Haeckel, E., 1860a. Uber neue, lebende Radiolarien des Mittelmeeres und ... die dazu gehorigen Abbildungen. Konig. Preuss. Akad. Wissen. Berlin, Monat. Jahre, 1860:794-817.

$1860 \mathrm{~b}$. Fernere Abbildungen und Diagnosen neuer Gattungen und Arten von lebenden Radiolarien des Mittelmeeres. Konig. Preuss. Akad. Wissen. Berlin, Monat. Jahre, 1860:835-845. 1862. Die Radiolarien (Rhizopoda Radiaria): Berlin (Reimer), Vol. xiv plus Atlas.

1887. Report on the Radiolaria collected by H.M.S. Challenger during the years 1873-1876. Report on the Scientific Results of the Voyage of the H.M.S. Challenger, Zoology, 18:clxxxviii + 1803.

Hays, J. D., 1965. Radiolaria and late Tertiary and Quaternary history of Antarctic Seas. Biology of Antarctic Seas II. Am. Geophys. Union, Antarctic Res. Ser., 5:125-184.

Johnson, D. A., Caulet, J. P., Nigrini, C., Schneider, D., and Kent, D., in press. Pliocene-Pleistocene radiolarian events and magnetostratigraphic calibrations for the tropical Indian Ocean. Mar. Micropaleontol.

Jörgensen, E., 1900. Protophyten und Protozoen im Planktonaus der norwegischen Westkuste. Bergens Museums Aarbog (1899), 2 (6): $1-112$.

1905. The protist plankton and the diatoms in bottom samples. Bergens Museums Skrifter, Bergen, 1905:49-151.

Kling, S. A., 1973. Radiolaria from the eastern North Pacific, Deep Sea Drilling Project Leg 18. In Kulm, L. D., von Huene, R., et al., Init. Repts. DSDP, 18: Washington (U.S. Govt. Printing Office), 617-671.

1977. Local and regional imprints on radiolarian assemblages from California coastal basin sediments. Mar. Micropaleontol., 2:207-221.
Knoll, A. H., and Johnson, D. A., 1975. Late Pleistocene evolution of the collosphaerid radiolarian Buccinosphaera invaginata Haeckel. Micropaleontology, 21:60-68.

Kruglikova, S. B., 1979. Radiolarians of the bottom sediments as indicators of environmental changes. Pacific Science Association XIV Pacific Science Congress, USSR Khabarovsk, August 1979. Committee F (Marine Sciences), Section F II (Marine Biology), Abstracts:145-147.

Lazarus, D. B., Reed, P. S. and Prothero, D. R., 1985. Evolution of the radiolarian species-complex Pterocanium: a preliminary survey. J. Paleontol., 59:183-220.

Martin, G. C., 1904. Radiolaria. Maryland Geol. Surv. (Johns Hopkins Press, Baltimore), 447-459.

Moore, T. C., 1971. Radiolaria. In Tracey, J. I., Jr., Sutton, G. H., et al., Init. Repts. DSDP , 8: Washington (U.S. Govt. Printing Office), $727-775$.

1972. Mid-Tertiary evolution of the radiolarian genus Calocycletta. Micropaleontology, 18:144-152.

Morley, J. J., and Shackleton, N. L., 1978. Extension of the radiolarian Stylatractus universus as a biostratigraphic datum to the Atlantic ocean. Geology, 6:309-311.

Müller, J., 1855. Uber die im Hafen von Messina beobachteten Polycystinen. Konig. Preuss. Akad. Wissens. Berlin, Monat. Jahre, 1855:671-674.

1857. Uber die Thalassicollen, Polycystinen und Acanthometren des Mittelmeeres. Konig. Preuss. Akad. Wissen. Berlin, Monat. Jahre, 1856:474-503

1858. Uber die Thalassicollen, Polycystinen und Acanthometren des Mittelmeeres. Konig. Preuss. Akad. Wissens. Berlin, Abh. Jahre, 1858:1-62.

Muizon, C. de, and Bellon, H., 1980. L'âge Mio-Pliocéne de la Formation Pisco, Peru. C. R. Acad. Sci., 290:1063-1066.

Nakaseko, K., 1963. Neogene Cyrtoidea (Radiolaria) from the Isozaki Formation in Ibaraki Prefecture. Japan Sci. Repts., 12:165-198 (College of General Education, Osaka Univ.).

Nigrini, C., 1967. Radiolaria in pelagic sediments from the Indian and Atlantic Oceans. Bull. Scripps Inst. Oceanogr., 11:1-125 (Univ. of California, San Diego.

1968. Radiolaria from eastern tropical Pacific sediments. Micropaleontology, 14:1-63.

1970. Radiolarian assemblages in the north Pacific and their application to a study of Quaternary sediments in Core V20-130. Geol. Soc. Am. Mem., 126:139-183.

1971. Radiolarian zones in the Quaternary of the equatorial Pacific Ocean. In Funnell, B. M., and Riedel, W. R. (Eds.), The Micropalaeontology of Oceans: Cambridge (Cambridge Univ. Press), 443-461.

1977. Tropical Cenozoic Artostrobiidae (Radiolaria) Micropaleontology, 23:241-269.

1985, Radiolarian biostratigraphy in the central equatorial Pacific. In Mayer, L. A., Theyer, F., et al., Init. Repts. DSDP, 85: Washington (U.S. Govt. Printing Office), 511-551.

Nigrini, C., and Moore, T. C., 1979. A guide to modern Radiolaria. Cushman Found. Foramin. Res. Spec. Publ., 16:i-xii, S1-S142, N1-N106.

Petrushevskaya, M. G., 1967. Radiolyarii otryadov i Nassellaria antarkticheskoi oblasti. Iss. Fauny Morei 4 (12), Resultaty Biologicheskikh Issledovanii Sovetskoi Antarkticheskoi Ekspeditsii 1955-1958, 3, Zoologicheskii Institut Academiya Nauk SSSR, $1-186$.

1971. Radiolyarii Nassellaria v planktone mirovogo okeana. Akademiya nauk SSSR, Zoologicheskii Institut, Iss. Fauny Morei, 9 (17): 1-294.

1975. Cenozoic radiolarians of the Antarctic, Leg 29, DSDP. In Kennett, J. P., Houtz, R. E., et al., Init. Repts. DSDP, 29: Washington (U. S. Govt. Printing Office), 541-675.

Petrushevskaya, M. G., and Kozlova, G. E., 1972. Radiolaria: Leg 14, Deep Sea Drilling Project. In Hayes, D. E., Pimm, A. C., et al., Init. Repts. DSDP, 14: Washington (U.S. Govt. Printing Office), 495-648.

Popofsky, A., 1908. Die Radiolarien der Antarktis (mit Ausnahme der Tripyleen). Deutsche Sudpolar-Expedition, 1901-1903, 10 (Zool. vol. 2): $183-305$. 
1913 Die Nassellarien des Warmwassergebietes. Deutsche Sudpolar-Expedition, 1901-1903, 14 (Zool. vol. 6):217-416.

Riedel, W. R., 1953. Mesozoic and late Tertiary Radiolaria of Rotti. J. Paleontol., 27:805-813.

1957. Radiolaria: a preliminary stratigraphy. Repts. Swedish Deep-Sea Expedition, 1947-1948, 6:59-96.

1958. Radiolaria in Antarctic sediments. Repts. BANZ Antarctic Res. Expedition, Ser. B, 6:217-255.

1959. Oligocene and Lower Miocene Radiolaria in tropical Pacific sediments. Micropaleontology, 5:285-302.

Riedel, W. R., and Sanfilippo, A., 1970. Radiolaria, Leg 4, Deep Sea Drilling Project. In Bader, R. G., Gerard, R. D., et al., Init. Repts. DSDP , 4: Washington (U.S. Govt. Printing Office), 503-575. 1971. Cenozoic Radiolaria from the western tropical Pacific, Leg 7. In Winterer, E. L., Riedel, W. R., et al., Init. Repts. DSDP, 7: Washington (U.S. Govt. Printing Office), 1529-1672. 1978. Stratigraphy and evolution of tropical Cenozoic radiolarians. Micropaleontology, 24:61-96.

Sanfilippo, A., and Riedel, W. R., 1970. Post-Eocene "closed" theoperid radiolarians. Micropaleontology, 16:446-462.

1973. Cenozoic Radiolaria (exclusive of theoperids, artostrobiids and amphipyndacids) from the Gulf of Mexico, DSDP Leg 10. In Worzel, J. L., Bryant, W., et al., Init. Repts. DSDP, 10: Washington (U. S. Govt. Printing Office), 475-611. 1980. A revised generic and suprageneric classification of the Artiscins (Radiolaria). J. Paleontol., 54:1008-1011.

Sanfilippo, A., Burckle, L. H., Martini, E. and Riedel, W. R., 1973. Radiolarians, diatoms, silicoflagellates and calcareous nannofossils in the Mediterranean Neogene. Micropaleontology, 19:209234.

Sanfilippo, A., Westberg-Smith, M. J. and Riedel, W. R., 1985. Cenozoic Radiolaria. In Bolli, H. M., Perch-Nielsen, K., and Saunders, J. B. (Eds.), Plankton Stratigraphy: Cambridge (Cambridge Univ. Press), 631-712.

Seguenza, G., 1880. Le formazioni terziarie nella provincia di Reggio (Calabria). Mem. R. Accadem. Lincei. Ser. 3, 6:1-446.

Stohr, E., 1880. Die Radiolarien fauna der Tripoli von Grotte, Provinz Girgenti in Sicilien. Palaeontographica, 26:71-124.

Streeter, L. S., 1988. Two species (one new) of Plio-Pleistocene Radiolaria from the central equatorial Indian Ocean. Micropaleontology, 34:63-66.

Strelkov, A. A., and Reshetnyak, V. V., 1971. Kolonialnye radiolyarii Spumellaria Mirovogo okeana (Colonial Spumellarian radiolarians of the world ocean). Akad. SSSR, Zoologich. Inst. Issl. Fauny Morei, 9 (17):295-418.

Seuss, E. and Thiede, J. (Eds.), 1983. Coastal Upwelling. Its sediment record. Part A: Responses of the Sedimentary Regime to Present Coastal Upwelling. NATO Conf. Ser. IV (Mar. Sci.).

Suess, E., von Huene, R., et al., 1988. Proc. ODP, Init. Repts., 112: College Station, TX (Ocean Drilling Program).

Theide, J. and Seuss, E. (Eds.), 1983. Coastal Upwelling. Its Sediment Record. Part B: Sedimentary Records of Ancient Coastal Upwelling. NATO Conf. Ser. IV (Mar. Sci.).

Vinassa de Regny, P. E., 1900. Radiolari Miocenici Italiani. Mem. $R$. Accad. Sci. Istit. Bologna, Ser. 5, 8:227-257 (565-595).

Date of initial receipt: 12 December 1988

Date of acceptance: 30 June 1989

Ms 112B-182

\section{APPENDIX A}

\section{Species List}

Acanthodesmia micropora (Popofsky). Semantis micropora Popofsky, 1908, p. 268, Pl. 20, Fig.4. Acanthodesmia micropora (Popofsky) in Petrushevskaya, 1971, p. 279, Fig. 135, I-IX.

Acanthodesmia viniculata (Müller). Lithocircus viniculatus Müller, 1857, p. 484. Acanthodesmia viniculata (Müller) in Müller, 1858, p. 30 , Pl. 1, Figs. 1-7.

Acrosphaera cyrtodon (Haeckel). Odontosphaera cyrtodon Haeckel, 1887 , p. 102, Pl. 5, Fig. 6. Acrosphaera cyrtodon (Haeckel) in Strelkov and Reshetnyak, 1971, p. 344, Pl. 7, Fig. 51; Pl. 8, Fig. 54; Text-Fig. 24.
Acrosphaera murrayana (Haeckel). Choenicosphaera murrayana Haeckel, 1887, p. 102, PI. 8, Fig. 4. Acrosphaera murrayana (Haeckel) in Hilmers, 1906, p. 63.

Acrosphaera pseudarktios Caulet, Caulet, 1986, p. 226, Pl. 1, Fig. 8.

Acrosphaera trepanata (Haeckel). Trypanosphaera trepanata Haeckel, 1887, p. 110, Pl. 5, Fig. 4. Acrosphaera trepanata (Haeckel), in Goll, 1980, p. 436, Pl. 2, Figs. 6-9.

Actinomma delicatulum (Dogiel). Heliosoma delicatulum Dogiel, Dogiel and Reshetnyak, 1952, p. 7, Fig. 2.

Actinomma haysi Bjorklund, Bjorklund, 1977, p. 117, Pl. 1, Figs. A-L.

Actinomma popofskii (Petrushevskaya). Echinomma popofskii Petrushevskaya, 1967, p. 23, Fig. 12, I-III.

Amphiplecta acrostoma Haeckel, 1887, p. 1223, Pl. 97, Fig. 10.

Amphirhopalum virchowi (Haeckel). Euchitonia virchowi Haeckel, 1862 , p. 503, Pl. 30, Figs. 1-4. Amphirhopalum virchowi (Haeckel) in Dumitrica, 1973, p. 835, Pl. 9, Figs. 2-4; PI. 11, Fig. 6; Pl. 21, Figs 2-13.

Amphiropalum ypsilon Haeckel, 1887, p. 522; Nigrini, 1971, p.447, Pl. 34, Figs. 7a-c.

Anthocyrtidium ehrenbergi (Stöhr). Anthocyrtis ehrenbergi Stöhr, 1880 , p. 100, Pl. 3, Figs. 21a,b. Anthocyrtidium ehrenbergi (Stöhr) in Nigrini and Caulet, 1988, p. 345, Pl. 1, Figs. 3, 4.

Anthocyrtidium jenghisi Streeter, Streeter, 1988, p. 63, Pl. 1, Figs. 1-4. Anthocyrtidium nosicaae Caulet, 1979, p. 132, Pl. 2, Fig. 6.

Anthocyrtidium ophirense (Ehrenberg). Anthocyrtis ophirensis Ehrenberg, 1872a, p. 301. Anthocyrtidium ophirense (Ehrenberg) in Nigrini, 1967, p. 56, Pl. 6, Fig. 3.

Anthocyrtidium pliocenica (Seguenza). Anthocyrtis ehrenbergi Stöhr var. pliocenica Seguenza, 1880, p. 232. Anthocyrtidium pliocenica (Seguenza) in Nigrini and Caulet, 1988, p. 355, Pl. 2, Figs. 5, 60.

Anthocyrtidium zanguebaricum (Ehrenberg). Anthocyrtis zanguebarica Ehrenberg, 1872a, p. 301. Anthocyrtidium zanguebaricum (Ehrenberg) in Nigrini, 1967, p. 58, Pl. 6, Fig. 4.

Axoprunum melpomene (Haeckel). Stylosphaera melpomene Haeckel, 1887 , p. 135 , Pl. 16, Fig. 1.

Botryostrobus aquilonaris (Bailey). Eucyrtidium aquilonaris Bailey, 1856, p. 4, Pl. 1, Fig. 9. Botryostrobus aquilonaris (Bailey) in Nigrini, 1977, p. 246, Pl. 1, Fig. 1.

Botryostrobus auritus/australis (Ehrenberg) gr. Lithocampe australe Ehrenberg, 1844, p. 187; 1854a, Pl. 35A, 21, Fig. 18. Botryostrobus auritus/australis (Ehrenberg) gr. in Nigrini, 1977, p. 246, Pl. 1, Figs. 2-5.

Botryostrobus bramlettei (Campbell and Clark), Lithomitra bramlettei Campbell and Clark, 1944, p. 53, Pl. 7, Figs. 10-14. Botryostrobus bramlettei (Campbell and Clark) in Caulet, 1979, p. 129, Pl. 1, Fig. 8.

Botryostrobus bramlettei pretumidulus Caulet, 1979, p. 129, PI. 1, Fig. 5. Botryostrobus bramlettei tumidulus (Bailey). Eucyrtidium tumidulus Bailey, 1856, p. 5, PI. 1, Fig. 11. Botryostrobus bramlettei tumidulus (Bailey) in Caulet, 1979, p. 131, Pl. 1, Fig. 9.

Botryostrobus miralestensis (Campbell and Clark). Dictyocephalus miralestensis Campbell and Clark, 1944, p. 45, Pl. 6, Figs. 12-14. Botryostrobus miralestensis (Campbell and Clark) in Petrushevskaya and Kozlova, 1972, 539, Pl. 24, Fig. 31.

Botryostrobus seriatus (Jorgensen). Eucyrtidium seriatum Jorgensen, 1902, p. 150. Stichocorys seriata (Jorgensen) in Jorgensen, 1905, p. 140, Pl. 18, Fig. 102-104.

Calocyclas semipolita group Clark and Campbell, Campbell and Clark, 1942, p.83, PI. 8, Figs. 12, 14, 17-19, 21-23.

Calocycletta caepa Moore, Moore, 1972, p. 149, Pl. 2, Figs. 4-7.

Calocycletta costata (Riedel). Calocyclas costata Riedel, 1959, p. 296, Pl. 2, Fig. 9.

Calocycletta robusta Moore, Moore, 1971, p. 743, Pl. 10, Figs. 5, 6.

Calocycletta virginis (Haeckel). Calocyclas virginis Haeckel, 1887, p. 1381, Pl. 74, Fig. 4. Calocycletta virginis (Haeckel) in Riedel and Sanfilippo, 1970, p. 535, Pl. 14, Fig. 10.

Calocycloma ampulla (Ehrenberg). Eucyrtidium ampulla Ehrenberg, 1854b, Pl. 36, Figs. 15a-c; Ehrenberg, 1873, p. 225. Calocycloma ampulla (Ehrenberg) in Foreman, 1973, p. 434, Pl. 1, Figs. 1-5; Pl. 9, Fig. 20.

Carpocanium sp. A Nigrini, Nigrini 1968, p. 55, Pl. 1, Fig. 4.

Carpocanopsis favosa (Haeckel). Cycladophora favosa Haeckel, 1887, p. 1380, Pl. 62, Figs. 5-6. Carpocanopsis favosa (Haeckel) in Sanfilippo et al., 1973, p. 224, Pl. 6, Figs. 7-8. 
Centrobotrys petrushevskayae Sanfilippo and Riedel, Sanfilippo and Riedel, 1973, p. 532, Pl. 36, Figs. 12, 13.

Ceratocyrtis histricosa group (Jorgensen). Helotholus histricosa Jorgensen, 1905, p. 137, Pl. 16, Figs. 86-88. Ceratocyrtis histricosa (Jorgensen) in Petrushevskaya, 1971, p. 98, Fig. 52, II-IV.

Circodiscus microporus (Stöhr). Trematodiscus microporus Stohr, 1880, p. 108, Pl. 4, Fig. 17. Circodiscus microporus (Stöhr) in Petrushevskaya and Kozlova, 1972, p.526, Pl. 19, Figs. 1-7.

Clathrocanium sphaerocephalum Haeckel, 1887, p. 1211, Pl. 64, Fig. 1.

Clathrocyclas alcmenae Haeckel, 1887, p. 1388, PI. 59, Fig. 6.

Clathrocyclas cabrilloensis gr. Campbell and Clark, 1944, p. 48, PI. 7, Fig. 1-3.

Collosphaera orthoconus (Haeckel). Conosphaera orthoconus Haeckel, 1887, p. 221, Pl. 12, Fig. 2. Collosphaera sp. A Knoll and Johnson, 1975 , p. 63, Pl. 1, Figs. 1, 2, 7, PI. 2, Figs. 4-6. Collosphaera orthoconus (Haeckel) in Bjorklund and Goll, 1979, p. 1317.

Collosphaera polygona group Haeckel, 1887, p. 96, PI. 5, Fig. 13.

Collosphaera tuberosa Haeckel, 1887, p. 97; Nigrini, 1971, p. 445, Pl. 34. 1, Fig. 1

Cycladophora davisiana (Ehrenberg). Cycladophora (?) davisiana Ehrenberg, 1861, p. 297. Theocalyptra davisiana (Ehrenberg) in Riedel, 1958, p. 239, Pl. 4, Figs. 2, 3, Text-Fig. 10.

Cypassis irregularis Nigrini, Nigrini, 1968, p. 53, Pl. 1, Figs. 2a-c.

Cyrtocapsella elongata (Nakaseko). Theocapsa elongata Nakaseko, 1963 , p. 185, Pl. 3, Figs. 4-5. Cyrtocapsella elongata (Nakaseko) in Sanfilippo and Riedel, 1970, p. 452, Pl. 1, Figs. 11-12.

Cyrtocapsella cornuta (Haeckel). Cyrtocapsa (Cyrtocapsella) cornuta Haeckel, 1887, p. 1513, Pl. 78, Fig. 9. Cyrtocapsella cornuta (Haeckel) in Sanfilippo and Riedel, 1970, p. 453, Pl. 1.

Cyrtocapsella japonica (Nakaseko). Eusyringium japonicum Nakaseko, 1963, p. 193, Pl. 4, Figs. 1-3. Cyrtocapsella japonica (Nakaseko) in Sanfilippo and Riedel, 1970, p. 452, Pl. 1, Figs. 13-15.

Cyrtocapsella tetrapera (Haeckel). Cyrtocapsa (Cyrtocapsella) tetrapera Haeckel, 1887, p. 1512, Pl. 75, Fig. 12. Cyrtocapsella tetrapera (Haeckel) in Sanfilippo and Riedel, 1970, p. 453, Pl. 1, Figs. 16-18.

Dendrospyris bursa Sanfilippo and Riedel in Sanfilippo et al., 1973, p. 217, Pl. 2, Figs. 9-13.

Desmospyris biceps (Ehrenberg). Lithobotrys biceps Ehrenberg, 1872b, Pl. 9, Fig. 23. Desmospyris biceps (Ehrenberg) in Caulet, 1979, p. 136, Pl. 4, Fig. 9.

Desmospyris stabilis (Goll). Dendrospyris stabilis Goll, 1968, p. 1422, Pl. 173, Figs. 16-18, 20. Desmospyris stabilis (Goll), in Caulet, 1985 , p. 852.

Diartus hughesi (Campbell and Clark). Ommatocampe hughesi Campbell and Clark, 1944, p. 23, Pl. 3, Fig. 12. Diartus hughesi (Campbell and Clark) in Sanfilippo and Riedel, 1980, p.1010, text-Fig. $1 \mathrm{i}$.

Diartus petterssoni (Riedel and Sanfilippo). Cannartus (?) petterssoni Riedel and Sanfilippo, 1970, p. 520, Pl. 14, Fig, 3. Diartus petterssoni (Riedel and Sanfilippo), in Sanfilippo and Riedel, 1980, p. 1010.

Dictyophimus crisiae Ehrenberg, Ehrenberg, 1854a, p. 241; Nigrini, 1967 , p. 66 , Pl. 6, Figs. 7a, b.

Dictyophimus infabricatus Nigrini, 1968, p. 56, Pl. 1, Fig. 6.

Dictyophimus splendens (Campbell and Clark). Pterocorys (Pterocyrtidium) splendens Campbell and Clark, 1944, p. 46, Pl. 6, Figs 19, 20. Dictyophimus splendens (Campbell and Clark) in Caulet, 1985, p. 852.

Dictyoprora mongolfieri (Ehrenberg). Eucyrtidium mongolfieri Ehrenberg, 1854b, Pl. 36, Fig. 18, B lower. Dictyoprora mongolfieri (Ehrenberg) in Nigrini, 1977, p. 250, Pl. 4, Figs. 1, 2.

Didymocyrtis antepenultima (Riedel and Sanfilippo). Ommatartus antepenultima Riedel and Sanfilippo, 1970, p. 521, Pl. 14, Fig. 4. Didymocyrtis antepenultima (Riedel and Sanfilippo) in Sanfilippo and Riedel, 1980, p. 1010, text-Fig. 1.

Didymocyrtis avita (Riedel). Panartus avitus Riedel, 1953, p. 808, Pl. 84, Fig. 7. Didymocyrtis avita (Riedel) in Sanfilippo and Riedel, 1980 , p. 1010, text-Fig. 1.

Didymocyrtis (?) bassanii (Carnevale). Cannartidium bassanii Carnevale, 1908, p. 21, Pl. 3, Fig. 12. Didymocyrtis (?) bassanii (Carnevale) in Sanfilippo and Riedel, 1980, p. 1011.

Didymocyrtis laticonus (Riedel). Cannartus laticonus Riedel, 1959, p. 291, PI. 1, Fig. 5. Didymocyrtis laticonus (Riedel) in Sanfilippo and Riedel, 1980, p. 1010, text-Fig. 1e.
Didymocyrtis mammifera (Haeckel). Cannartidium mammiferum Haeckel, 1887, p. 375 , Pl. 39, Fig. 16. Didymocyrtis mammifera (Haeckel) in Sanfilippo and Riedel, 1980, p. 1010.

Didymocyrtis penultima (Riedel). Panarium penultimum Riedel, 1957, p. 76, PI. 1, Fig. 1. Didymocyrtis penultima (Riedel) in Sanfilippo and Riedel, 1980, p. 1010.

Didymocyrtis prismatica (Haeckel). Pipettella prismatica Haeckel, 1887, p. 305, Pl. 39, Fig. 6. Didymocyrtis prismaticus (Haeckel) in Sanfilippo and Riedel, 1980, p. 1010, text-Fig. 1c.

Didymocyrtis tetrathalamus (Haeckel). Panartus tetrathalamus Haeckel, 1887, p. 378, Pl. 40, Fig. 3. Didymocyrtis tetrathalamus (Haeckel) in Sanfilippo and Riedel, 1980, p. 1010, text-Fig. 1g.

Didymocyrtis tubaria (Haeckel). Pipettaria tubaria Haeckel, 1887, p. 339, Pl. 39, Fig. 15. Didymocyrtis tubaria (Haeckel) in Sanfilippo and Riedel, 1980, p. 1010.

Didymocyrtis violina (Haeckel). Cannartus violina Haeckel, 1887, p. 358, Pl. 39, Fig. 10. Didymocyrtis violina (Haeckel) in Sanfilippo and Riedel, 1980, p. 1010, text-Fig. 1.

Dorcadospyris ateuchus (Ehrenberg). Ceratospyris ateuchus Ehrenberg, 1873, p. 218; Ehrenberg, 1875, Pl. 21, Fig. 4. Dorcadospyris ateuchus (Ehrenberg), Riedel and Sanfilippo, 1970, p. 523.

Dorcadospyris dentata Haeckel, 1887, p. 1040, Pl. 85, Fig. 6.

Eucecryphalus cervus (Ehrenberg). Eucyrtidium cervus Ehrenberg, 1872a, p. 291; Ehrenberg, 1872b, Pl. 9, Fig. 21. Eucecryphalus cervus (Ehrenberg) in Petrushevskaya, 1971, p. 223, Fig. 104.

Eucecryphalus gegenbaueri Haeckel, Haeckel, 1860, p. 836; Haeckel, 1862 , Pl. 5, Figs. 12-15.

Eucyrtidium acuminatum (Ehrenberg). Lithocampe acuminata Ehrenberg, 1844, p. 84. Eucyrtidium acuminatum (Ehrenberg) in Ehrenberg, 1847, p. 43; Ehrenberg, 1854b, Pl. 22, Fig. 27.

Eucyrtidium anniae Caulet, 1985, p. 850, Pl. 5, Fig. 10.

Eucyrtidium anomalum (Haeckel). Lithocampe anomala Haeckel, 1860 , p. 839. Eucyrtidium anomalum (Haeckel) in Haeckel, 1862, p. 323 , Pl. 7, Figs. 11-13.

Eucyrtidium calvertense Martin, Martin, 1904, p. 450, PI. 130, Fig. 5.

Eucyrtidium cienkowskii Haeckel gr., Haeckel, 1887, p. 1493, Pl. 80, Fig. 9.

Eucyrtidium dufresni Caulet, 1979, p. 134, Pl. 3, Figs. 8, 9.

Eucyrtidium hexacolum (Haeckel). Lithocampe hexacola Haeckel, 1887 , p. 1507 , Pl. 79 , Fig. 7.

Eucyrtidium hexastichum (Haeckel). Lithostrobus hexastichus Haeckel, 1887, p. 1470, Pl. 80, Fig. 15. Eucyrtidium hexastichum (Haeckel) in Petrushevskaya, 1971, p. 220, Fig. 99, III-X.

Eucyrtidium indiensis Caulet, 1979, p. 134, Pl. 4, Fig. 5.

Eucyrtidium infundibulum (Haeckel). Lithomitra infundibulum Haeckel, 1887, p. 1487, Pl. 79, Fig. 5.

Eucyrtidium monumentum (Haeckel). Calocyclas monumentum Haeckel, 1887, p. 1385 , Pl. 73, Fig. 9.

Eucyrtidium octocolum (Haeckel). Lithocampe octocola Haeckel, 1887, p. 1508 , Pl. 79 , Fig. 6.

Eucyrtidium punctatum (Ehrenberg). Lithocampe punctata Ehrenberg, 1844, p. 84. Eucyrtidium punctatum (Ehrenberg) in Ehrenberg, 1847, p. 43; Ehrenberg, 1854b, Pl. 22, Fig. 24.

Eucyrtidium teuscheri (Haeckel) orthoporus Caulet, 1985, p. 851, Pl. 5, Fig. 4.

Eucyrtidium teuscheri (Haeckel) teuscheri Caulet, 1985, p. 851, Pl. 5, Figs. 5-8.

Eusyringium fistuligerum (Ehrenberg). Eucyrtidium fistuligerum Ehrenberg, 1873 , p. 229 ; 1875 , Pl. 9, Fig. 3. Eusyringium fistuligerum (Ehrenberg) in Riedel and Sanfilippo, 1970, p. 527, PI. 8, Figs. 8, 9.

Gondwanaria dogieli (Petrushevskaya). Sethoconus (?) dogieli Petrushevskaya, 1967, p. 95, Pl. 53, Figs. 1, 2. Gondwanaria dogieli (Petrushevskaya), in Petrushevskaya, 1975, p. 585.

Haliometta miocenica (Campbell and Clark). Heliosphaera miocenica Campbell and Clark, 1944, p. 16, Pl. 2, Figs. 10-14. Haliometta miocenica (Campbell and Clark), in Petrushevskaya and Kozlova, 1972, p. 517, Pl. 9, Figs. 8,9.

Heliodiscus asteriscus Haeckel, 1887, p. 445, Pl. 33, Fig. 8.

Histiastrum martinianum Carnevale group, Carnevale, 1908, p. 26, Pl. 4, Fig. 11; Sanfilippo et al., 1973, p. 217, Pl. 2, Figs. 7, 8.

Lamprocyclas gamphonycha (Jorgensen). Pterocorys gamphonyxos Jorgensen, 1900, p. 86. Androcyclas gamphonycha (Jorgensen), in 
Jorgensen, 1905, p. 139, PI. 17, Figs. 92-97. Lamprocyclas gamphonycha (Jorgensen), in Petrushevskaya, 1971, Fig. 117, I-III.

Lamprocyclas hannai (Campbell and Clark). Calocyclas hannai Cmapbell and Clark, 1944, p. 48, Pl. 69, Figs. 21, 22. Lamprocyclas hannai (Campbell and Clark) in Caulet, 1985, p. 852.

Lamprocyclas junonis (Haeckel). Theoconus junonis Haeckel, 1887, p. 1401, Pl. 69, Fig. 7. Lamprocyclas junonis (Haeckel) in Caulet, 1985 , p. 852 , Pl. 4, Fig. 10.

Lamprocyclas maritali group Haeckel, 1887, p. 1390, Pl. 74, Figs. 13, 14.

Lamprocyclas margatensis (Campbell and Clark). Calocyclas margatensis Campbell and Clark, 1944, p. 47, PI. 6, Figs. 17, 18. Lamprocyclas margatensis (Campbell and Clark) in Caulet, 1985, p. 852 , Pl. 4, Fig. 3 .

Lamprocyrtis daniellae Caulet, 1985, p. 850, Pl. 3, Figs. 13-16.

Lamprocyrtis heteroporos (Hays). Lamprocyclas heteroporos Hays, 1965, p. 179, Pl. 3, Fig. 1. Lamprocyrtis heteroporos (Hays), in Kling, 1973, p. 639, Pl. 5, Figs. 19-21, Pl. 15, Figs. 4-5.

Lamprocyrtis neoheteroporos Kling, 1973, p. 639, PI. 5, Figs. 17, 18, Pl. 15 , Figs. $4,5$.

Lamprocyrtis nigriniae (Caulet). Conarachnium nigriniae Caulet, 1971, p. 3, Pl. 3, Figs. 1-4, Pl. 4, Figs. 1-4. Lamprocyrtis nigriniae (Caulet), in Kling, 1977, p. 217, Pl. 1, Fig. 17.

Lampromitra coronata Haeckel, 1887, p. 1214, Pl. 60, Figs. 7, 7a.

Larcospira moschkovskii Kruglikova, Kruglikova, 1978, p. 88, Pl. 27, Figs. 3-6.

Liriospyris parkerae Riedel and Sanfilippo, Riedel and Sanfilippo, 1971, p. 1590, Pl. 2C, Fig. 15, Pl. 5, Fig. 4.

Liriospyris stauropora (Haeckel). Trissocyclus stauropora Haeckel, 1887 , p. 987, Pl. 83, Fig. 5. Liriospyris stauropora (Haeckel) in Goll, 1968, p. 1431, Pl. 175, Figs. 1-3, 7, text-Fig. 9.

Lithocyclia aristotelis gr. (Ehrenberg). Astromma aristotelis Ehrenberg, 1847, p. 55, Fig. 10. Lithocyclia aristotelis (Ehrenberg), in Riedel and Sanfilippo, 1970, p. 522.

Lithocyclia ocellus gr. Ehrenberg, 1854b, Pl. 36, Fig. 30; 1873, p. 240.

Lithostrobus hexagonalis Haeckel, 1887, p. 1475, PI. 79, Fig. 20.

(?) Lithostrobus undulatus (Popofsky). Artopilium undulatum Popofsky, 1913, p. 405, Pl. 36, Figs. 4, 5.

Lychnocanoma elongata (Vinassa de Regny). Tetrahedrina globosa Vinassa de Regny, 1900, p. 243, Pl. 2, Fig. 30. Lychnocanoma elongata (Vinassa de Regny) in Sanfilippo et al., 1973, p. 221, PI. 5, Figs. 19-20.

Nephrospyris renilla Haeckel, 1887, p. 1101, PI. 90, Figs. 9, 10.

Octopyle stenozona Haeckel, 1887, p. 652, Pl. 9, Fig. 11.

Periphaena decora Ehrenberg, 1873, p. 246; 1875, Pl. 28, Fig. 6.

Phormostichoartus (?) crustula (Caulet). Lithamphora crustula Caulet, 1979, p. 131, Pl. 2, Fig. 1.

Phormostichoartus fistula Nigrini, 1977, p. 153, PI. 1, Figs. 11-13.

Phormostichoartus furcaspiculata (Popofsky). Lithamphora furcaspiculata Popofsky, 1913, p. 408, Text-Figs. 138, 139. Phormostichoartus furcaspiculata (Popofsky) in Caulet, 1985, p. 853.

Phormostichoartus multiseriatus (Ehrenberg). Eucyrtidium multiseriatum Ehrenberg, 1860a, p. 768. Lithocampe (?) multiseriata (Ehrenberg) in Petrushevskaya, 1967, p. 135, Fig. 16, I-III. Phormostichoartus multiseriatus (Ehrenberg) in Caulet, 1985, p. 853.

Phormostichoartus platycephala (Ehrenberg). Eucyrtidium platycephalum Ehrenberg, 1872b, PI. 3, Fig. 16. Phormostichoartus plateycephala (Ehrenberg) in Caulet, 1985, p. 853, Pl. 3, Figs. 5, 6.

Phormostichoartus pitomorphus Caulet, 1985, p. 850, Pl. 3, Figs. 3, 4, 9, $10,12$.

Phorticium clevei (Jörgensen). Tetrapylonium clevei Jorgensen, 1900, p. 64. Phorticium clevei (Jörgensen) in Petrushevskaya, 1967, p. 58, Figs. 32-34.

Plectacantha cremastoplegma Nigrini, 1968, p. 55, Pl. 1, Fig. 3a-c, text-Fig. 2.

Podocyrtis papalis Ehrenberg, 1847, Fig. 2; 1854d, Pl. 36, Fig. 23; 1873, p. 251.

Prunopyle antarctica Dreyer, Dreyer, 1889, p. 24, PI. 5, Fig. 75

Prunopyle hayesi Chen, Chen, 1975, p. 454, Pl. 9, Figs. 3-5.

Pseudocubus vema (Hays). Helotholus vema Hays, 1965, p. 176, Pl. 2 , Fig. 3, Text-Fig. A. Pseudocubus vema (Hays) in Petrushevskaya, 1971, p. 46, Fig. 24, I-IV.

Pseudocubus warreni Goll, 1980, p. 437, Pl. 3, Figs. 5-6.
Pterocanium praetextum (Ehrenberg) eucolpum (Haeckel). Pterocanium eucolpum Haeckel, 1887, p. 1322, Pl. 73, Fig. 4. Pterocanium praetextum (Ehrenberg) eucolpum (Haeckel) in Nigrini, 1967, p. 70, PI. 7, Fig. 2.

Pterocanium grandiporus Nigrini, 1968, p. 57, Pl. 1, Fig. 7.

Pterocanium korotnevi (Dogiel). Pterocorys korotnevi Dogiel, Dogiel and Reshetnyak, 1952, p. 17, Fig. 11. Pterocanium korotnevi (Dogiel), Nigrini, 1970, p. 170, Pl. 3, Figs. 10, 11.

Pterocanium praetextum (Ehrenberg). Lychnocanium praetextum Ehrenberg, 1872a, p. 316; 1872b, p. 297, Pl. 10, Fig. 2. Pterocanium praetextum (Ehrenberg) in Nigrini, 1967, p. 68, Pl. 7, Fig. 1.

Pterocanium trilobum (Haeckel). Dictyopodium trilobum Haeckel, 1860 b, p. 839 ; 1862 , p. 340 , Pl. 8 , Figs. 6-10. Pterocanium trilobum (Haeckel) in Haeckel, 1887, p. 1333.

Pterocorys campanula Haeckel, 1887, p. 1316, Pl. 71, Fig. 3.

Pterocorys clausus (Popofsky). Lithornithium clausum Popofsky, 1913, p. 393, Text-Fig. 11. Pterocorys clausus (Popofsky) in Petrushevskaya and Kozlova, 1972, p. 545, Pl. 36, Figs. 16-18.

Pterocorys hertwigii (Haeckel). Eucyrtidium hertwigii Haeckel, 1887, p. 1491, Pl. 80, Fig. 12. Pterocorys hertwigii (Haeckel), in Nigrini, 1967 , p. 73 , Pl. 7, Figs. 4a, b.

Pterocorys macroceras (Popofsky). Lithopilium macroceras Popofsky, 1913, p. 377, Text-Figs. 91-93. Pterocorys macroceras (Popofsky) in Petrushevskaya, 1971, p. 234, Fig. 120.

Pterocorys minythorax (Nigrini). Theoconus minythorax Nigrini, 1968, p. 57, Pl. 1, Fig. 8. Pterocorys minythorax (Nigrini) in Nigrini and Moore, 1979, p. N87, Pl. 25, Fig. 10.

Pterocorys zancleus (Müller), Eucyrtidium zanclaeum Müller, 1855, p. $672 ; 1858$, p. 41, Pl. 6, Figs. 1-3. Pterocorys zancleus (Müller) in Petrushevskaya, 1971, p. 233, Fig. 119, i-vii.

Rhizosphaera antarctica (Haeckel). Spongoplegema antarctica Haeckel, 1887, p. 90. Rhizosphaera antarcticum (Haeckel) in Caulet, 1985, p. 853.

Rhopalastrum profunda (Ehrenberg) group. Dictyocoryne profunda Ehrenberg, 1860a, p. 767; 1872b, Pl. 7, Fig. 23. Rhopalastrum profunda (Ehrenberg) gr. in Petrushevskaya and Kozlova, 1972, p. 529, Pl. 17, Figs. 4-6, Pl. 20, Fig. 8.

Saturnalis circularis Haeckel, 1887, p. 131

Siphocampe arachnea (Ehrenberg) group. Eucyrtidium lineatum arachneum Ehrenberg, 1861, p. 299. Lithomitra arachnea (Ehrenberg) in Riedel, 1958, p. 242, Pl. 4, Figs. 7, 8. Siphocampe arachnea (Ehrenberg) gr. in Nigrini, 1977, p. 255, Pl. 3, Figs. 7, 8.

Siphocampe caryoforma (Caulet). Lithamphora caryoforma Caulet, 1979, p. 131, Pl. 2, Fig. 2.

Siphocampe modeloensis (Campbell and Clark). Lithocampe modeloensis Campbell and Clark, 1944, p. 59, Pl. 7, Figs. 28-30. Siphocampe modeloensis (Campbell and Clark) in Caulet, 1985, p. 853.

Siphostichartus corona (Haeckel). Cyrtophormis (Acanthocyrtis) corona Haeckel, 1887 , p. 1462, Pl. 77, Fig. 15. Siphostichartus corona (Haeckel) in Nigrini, 1977, p. 257, Pl. 2, Figs. 5, 6, 7.

Siphostichartus praecorona Nigrini, 1977, p. 258, Pl. 2, Figs. 8, 9.

Spirocyrtis subscalaris Nigrini, 1977, p. 259, Pl. 3, Figs. 1, 2.

Spirocyrtis subtilis Petrushevskaya, 1972, in Petrushevskaya and Kozlova, 1972, p. 540, Pl. 24, Figs. 22-24.

Spongaster tetras Ehrenberg, Ehrenberg, 1860b, p.833; 1872b, p. 299, Pl. IV (iii), Fig. 8.

Spongocore puella Haeckel, 1887, p. 347, Pl. 48, Fig. 6.

Spongodiscus osculosus (Dreyer). Spongopyle osculosa Dreyer, 1889, p. 42, Figs. 99, 100. Spongodiscus osculosus (Dreyer) in Petrushevskaya, 1967, p. 42, Figs. 20-22.

Spongodiscus setosus (Dreyer). Spongopyle setosa Dreyer, 1889, p. 43, Pl. 6, Figs. 97, 98. Spongodiscus (?) setosus (Dreyer) in Petrushevskaya, 1967, p. 39, Fig. 20, III-V.

Spongotrochus glacialis Popofsky, 1908, p. 228, PI. 27, Fig. 1, PI. 28, Fig. 2.

Stichocorys armata (Haeckel). Cyrtophormis armata Haeckel, 1887, p. 1460, PI. 78, Fig. 17. Stichocorys armata (Haeckel) in Riedel and Sanfilippo, 1971, p. 1595, Pl. 2E, Figs. 13-15.

Stichocorys delmontensis (Campbell and Clark). Eucyrtidium delmontensis Campbell and Clark, 1944, p. 56, Pl. 7, Figs. 19, 20. Stichocorys delmontensis (Campbell and Clark) in Sanfilippo and Riedel, 1970, p. 451, PI. 1, Fig. 9. 
Stichocorys peregrina (Riedel). Eucyrtidium elongatum peregrinum Riedel, 1953, p. 812, PI. 85, Fig. 2. Stichocorys peregrina (Riedel) in Sanfilippo and Riedel, 1970, p. 451, PI. 1, Fig. 10.

Stichocorys radicula (Ehrenberg). Lithocampe radicula Ehrenberg, 1838 , p. 130 , Pl. 4, Fig. 11g.

Stichocorys wolffii Haeckel, 1887, p. 1479, Pl. 80, Fig. 10.

Stichopodium biconicum (Vinassa de Regny). Lithocampe biconica Vinassa de Regny, 1900, Pl. 3, Fig. 30. Stichopodium biconicum (Vinassa de Regny) in Petrushevskaya, 1975, p. 581, Pl. 14, Figs. 25-27, PI. 26, Figs. 9, 10.

Stichopilium bicorne Haeckel, 1887, p. 1437, PI. 77, Fig. 9.

Streblacantha circumtexta (Jörgensen). Sorolarcus circumtextus Jörgensen, 1900, p. 65. Streblacantha circumtexta (Jörgensen) in Jörgensen, 1905, p. 121, Pl. 11, 12, Fig. 46.

Stylatractus universus Hays, 1970, p. 215, Pl. 1, Figs. 1, 2.

Stylosphaera angelina Campbell and Clark, 1944, p. 12, PI. 1, Figs. 15, 20.

Tepka perforata Sanfilippo and Riedel, 1973, p. 228, PI. 6, Figs. 18-20. Tessarospyris pododendros Carnevale, 1908, p. 28, PI. 3, Fig. 18.

Theocalyptra (?) cornutoides (Petrushevskaya). Cycladophora davisiana (Ehrenberg) cornutoides Petrushevskaya, 1967, p. 124, Fig. 70, I-III.

Theocorythium trachelium (Ehrenberg). Eucyrtidium trachelius Ehrenberg, 1872a, p. 312. Theocorythium trachelium (Ehrenberg) in Nigrini, 1967, p. 79, Pl. 8, Fig. 2, Pl. 9, Fig. 2.

Theocorythium vetulum Nigrini, 1971, p. 447, Pl. 34.1, Figs. 6a, 6b.
Theocyrtis tuberosa Riedel, Riedel, 1959, p. 298, Pl. 2, Figs. 10, 11.

Tholospyris capoi (Goll). Phormospyris stabilis capoi Goll, 1976, p. 392, Pl. 5, Figs. 1-2; Pl. 6; Pl. 7.

Tholospyris scaphipes (Haeckel). Tristylospyris scaphipes Haeckel, 1887 , p. 1033, Pl. 84, Fig. 13. Tholospyris scaphipes (Haeckel) in Goll, 1969, p. 328, Pl. 58, Figs. 1-6.

Tricolocampe cylindrica Haeckel, 1887, p. 1412, PI. 66, Fig. 21.

Tricolocapsa papillosa (Ehrenberg) group. Eucyrtidium papillosum Ehrenberg, 1872a, p. $310 ; 1872$ b, Pl. 7, Fig. 10. Tricolocapsa papillosa (Ehrenberg) gr. in Petrushevskaya and Kozlova, 1972, p. 537, Pl. 22, Fig. 31.

Tricolospyris baconiana Haeckel, 1887, p. 1098, Pl. 88, Fig. 8. Tympanomma binoctonum (Haeckel). Tympanidium binoctonum Haeckel, 1887, p. 1004, Pl. 94, Fig. 18. Tympanomma binoctonum (Haeckel) in Petrushevskaya and Kozlova, 1972, p. 533, Pl. 39, Figs. 23-24.

\section{APPENDIX B}

Raw Data for Leg 112 Holes 682A, 683A, 685A, and 688A.

The following appendix is composed of raw data tables for some Leg 112 holes. This study does not record species abundances, but rather notes only presence or absence. Overall abundance is given in terms of $\mathrm{R}=$ rare, $\mathrm{F}=$ few, $\mathrm{C}=$ common, and $\mathrm{A}=$ abundant. Preservation is given in terms of $P=$ poor, $M=$ moderate, and $G=$ good. 
Hole 682A.

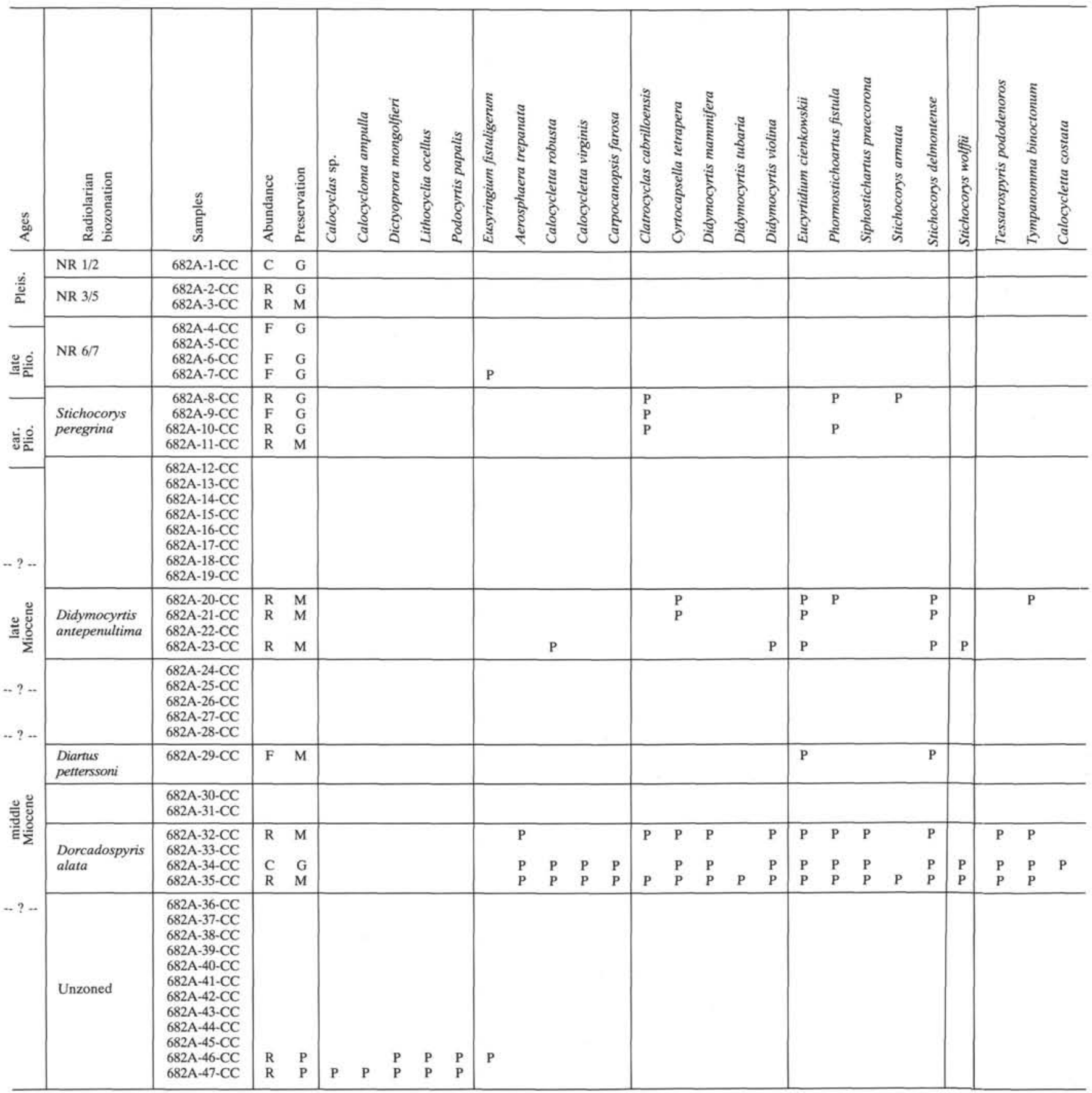


P. DE WEVER, J.-P. CAULET, J. BOURGOIS

Hole 682A (continued).

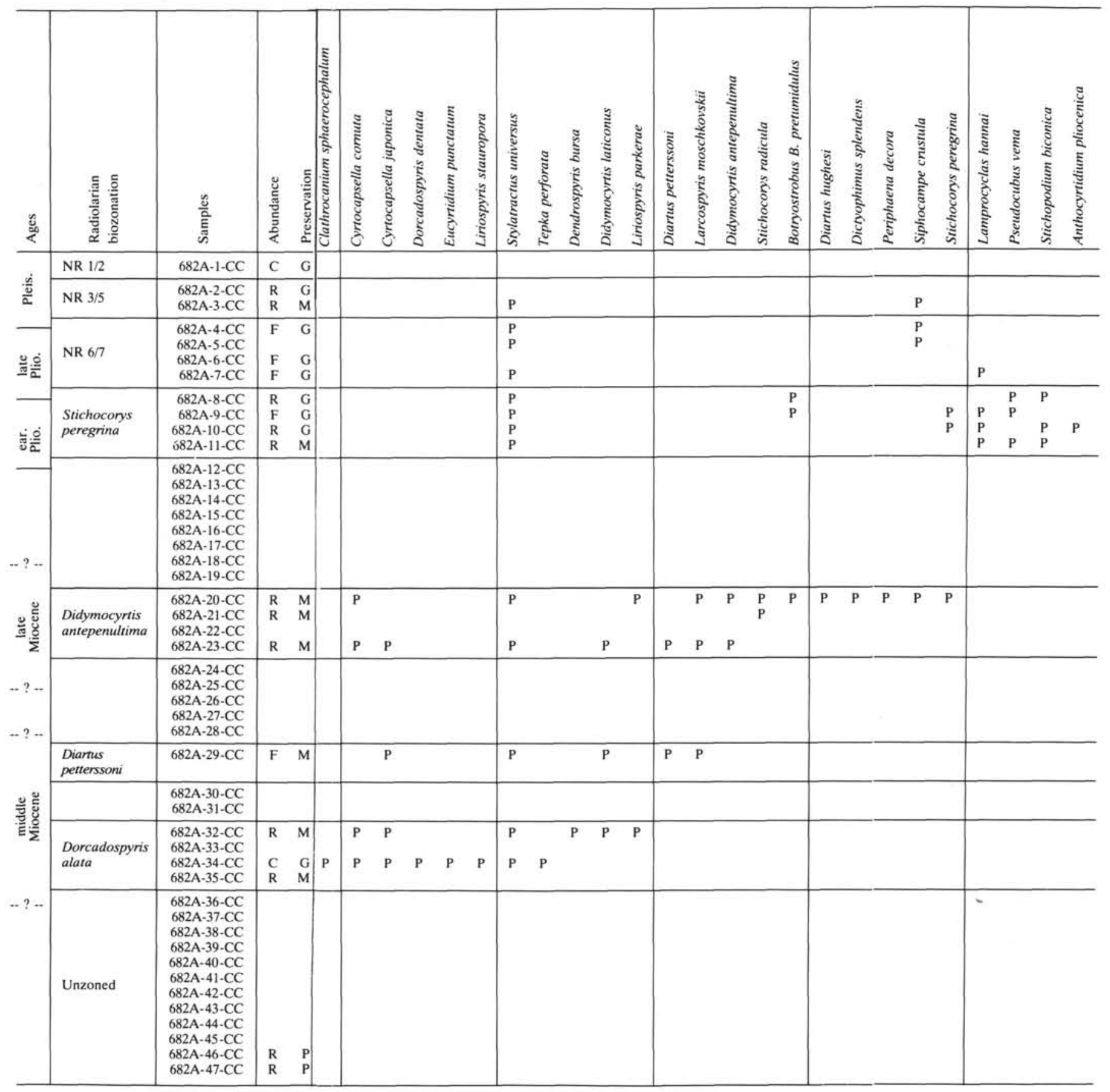

196 
Hole 682A (continued).

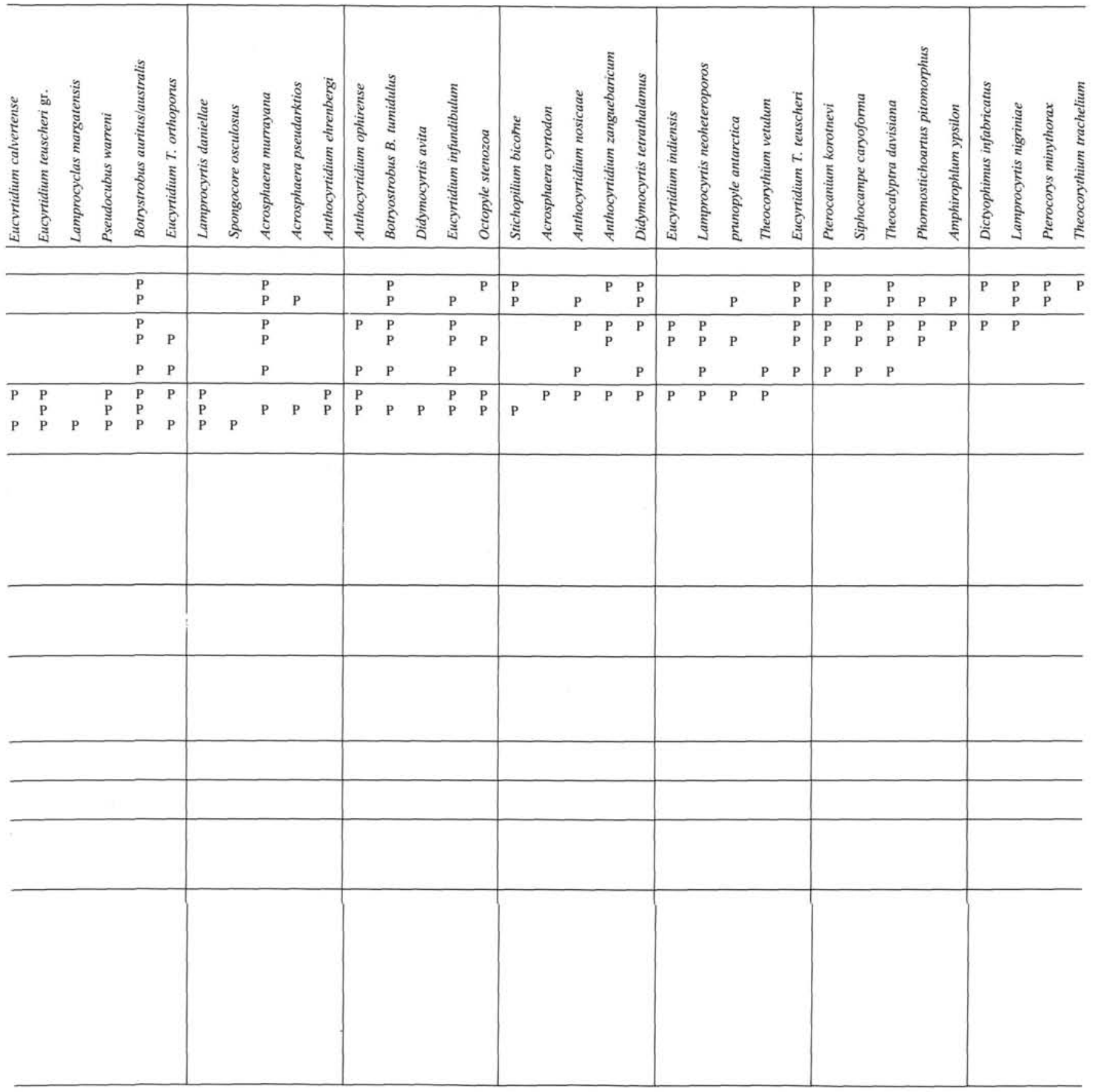


Hole 683A.

\begin{tabular}{|c|c|c|c|c|c|c|c|c|c|c|c|c|c|c|c|c|c|c|c|c|c|c|c|c|}
\hline 氉 & 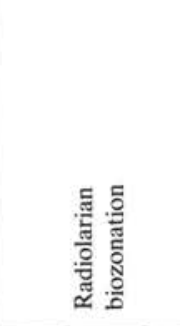 & 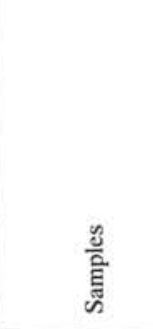 & 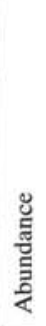 & 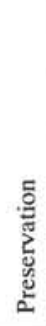 & 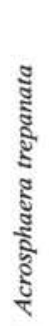 & 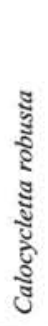 & 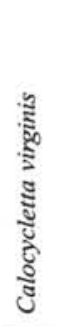 & 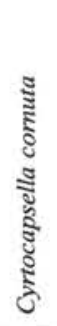 & 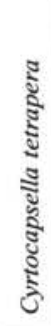 & 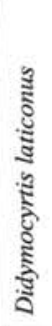 & 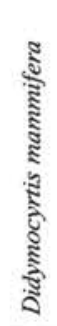 & 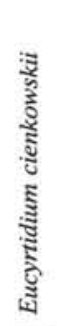 & 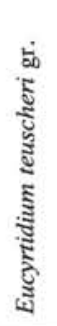 & 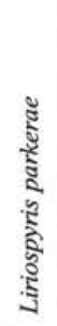 & $\begin{array}{l}\text { के } \\
\text { है } \\
\text { हुँ } \\
\text { हूँ }\end{array}$ & 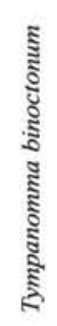 & 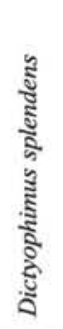 & 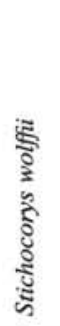 & 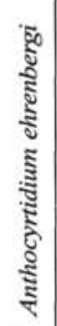 & 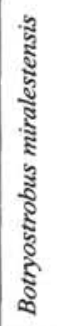 & 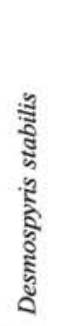 & 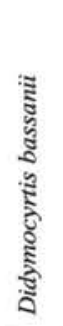 & 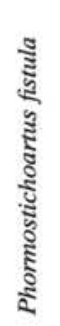 & 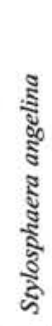 \\
\hline \multirow{3}{*}{$\begin{array}{l}\frac{\dddot{E}}{8} \\
\frac{0}{\frac{n}{0}} \\
\frac{0}{2}\end{array}$} & $\begin{array}{l}\text { NR } 1 \\
\text { NR } 2\end{array}$ & $\begin{array}{l}683 \mathrm{~A}-1-\mathrm{CC} \\
683 \mathrm{~A}-2-\mathrm{CC} \\
683 \mathrm{~A}-3-\mathrm{CC} \\
683 \mathrm{~A}-4-\mathrm{CC} \\
683 \mathrm{~A}-5-\mathrm{CC}\end{array}$ & $\begin{array}{l}\text { A } \\
\text { A } \\
\text { C } \\
\text { A } \\
\text { C }\end{array}$ & $\begin{array}{l}\text { G } \\
\text { G } \\
\text { G } \\
\text { G } \\
\text { G }\end{array}$ & $\begin{array}{l}\mathrm{P} \\
\mathrm{P} \\
\mathrm{P}\end{array}$ & & & & & & & & & & & & & & & & & & & \\
\hline & $\begin{array}{l}\text { NR } 3 \\
\text { to } \\
\text { NR } 7\end{array}$ & $\begin{array}{l}683 \mathrm{~A}-6-\mathrm{CC} \\
683 \mathrm{~A}-7-\mathrm{CC} \\
683 \mathrm{~A}-8-\mathrm{CC} \\
683 \mathrm{~A}-9-\mathrm{CC} \\
683 \mathrm{~A}-10-\mathrm{CC} \\
683 \mathrm{~A}-11-\mathrm{CC} \\
683 \mathrm{~A}-12-\mathrm{CC} \\
683 \mathrm{~A}-13-\mathrm{CC} \\
683 \mathrm{~A}-14-\mathrm{CC} \\
683 \mathrm{~A}-15-\mathrm{CC} \\
683 \mathrm{~A}-16-\mathrm{CC} \\
683 \mathrm{~A}-17-\mathrm{CC} \\
683 \mathrm{~A}-18-\mathrm{CC} \\
683 \mathrm{~A}-19-\mathrm{CC} \\
683 \mathrm{~A}-20-\mathrm{CC} \\
683 \mathrm{~A}-21-\mathrm{CC} \\
683 \mathrm{~A}-22-\mathrm{CC}\end{array}$ & $\begin{array}{l}\text { A } \\
\text { A } \\
\text { A } \\
\text { C } \\
\text { C } \\
\text { C } \\
\text { C } \\
\text { C } \\
\text { C } \\
\text { C } \\
\text { C } \\
\text { C } \\
\text { C } \\
\text { C } \\
\text { C } \\
\text { C }\end{array}$ & $\begin{array}{l}\text { G } \\
\text { G } \\
\text { G } \\
\text { G } \\
\text { G } \\
\text { G } \\
\text { G } \\
\text { G } \\
\text { G } \\
\text { G } \\
\text { G } \\
\text { G } \\
\\
\text { G } \\
\text { G } \\
\text { G } \\
\text { G }\end{array}$ & $\begin{array}{l}\mathrm{P} \\
\mathrm{P} \\
\mathrm{P} \\
\mathrm{P} \\
\mathrm{P} \\
\mathrm{P} \\
\mathrm{P} \\
\mathrm{P}\end{array}$ & & & & & & & & & & & & & & & & & & & \\
\hline & NR $8 / 9$ & $\begin{array}{l}683 \mathrm{~A}-23-\mathrm{CC} \\
683 \mathrm{~A}-24-\mathrm{CC} \\
683 \mathrm{~A}-25-\mathrm{CC}\end{array}$ & $\begin{array}{l}\mathrm{C} \\
\mathrm{C} \\
\mathrm{C}\end{array}$ & $\begin{array}{l}G \\
G \\
G\end{array}$ & $\begin{array}{l}\mathrm{P} \\
\mathrm{P} \\
\mathrm{P}\end{array}$ & & & & & & & & $\begin{array}{l}\mathrm{P} \\
\mathrm{P}\end{array}$ & & & & & & & & & & $\begin{array}{l}\mathrm{P} \\
\mathrm{P} \\
\mathrm{P}\end{array}$ & \\
\hline$\underset{\Xi}{\tilde{g}}$ & $\begin{array}{l}\text { Didymocyrtis } \\
\text { antepenultima }\end{array}$ & $\begin{array}{l}683 \mathrm{~A}-26-\mathrm{CC} \\
683 \mathrm{~A}-27-\mathrm{CC} \\
683 \mathrm{~A}-28-\mathrm{CC} \\
683 \mathrm{~A}-29-\mathrm{CC}\end{array}$ & $\begin{array}{l}\mathrm{F} \\
\mathrm{F} \\
\mathrm{C} \\
\mathrm{C}\end{array}$ & $\begin{array}{l}\mathrm{M} \\
\mathrm{M} \\
\mathrm{M} \\
\mathrm{G}\end{array}$ & $\begin{array}{l}P \\
P \\
P\end{array}$ & & & & $\mathrm{P}$ & $\begin{array}{l}P \\
P\end{array}$ & & $\begin{array}{l}\mathrm{P} \\
\mathrm{P} \\
\mathrm{P} \\
\mathrm{P}\end{array}$ & $\begin{array}{l}\mathrm{P} \\
\mathrm{P}\end{array}$ & & $\begin{array}{l}\mathrm{P} \\
\mathrm{P} \\
\mathrm{P}\end{array}$ & & $\begin{array}{l}\mathrm{P} \\
\mathrm{P} \\
\mathrm{P}\end{array}$ & $\begin{array}{l}\mathrm{P} \\
\mathrm{P}\end{array}$ & $\begin{array}{l}\mathrm{P} \\
\mathrm{P}\end{array}$ & $\begin{array}{l}\mathrm{P} \\
\mathrm{P}\end{array}$ & $\begin{array}{l}\mathrm{P} \\
\mathrm{P}\end{array}$ & & $\begin{array}{l}\mathrm{P} \\
\mathrm{P}\end{array}$ & $\mathrm{P}$ \\
\hline \multirow[t]{2}{*}{ 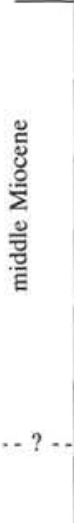 } & D. petterssoni & $\begin{array}{l}683 \mathrm{~A}-30-\mathrm{CC} \\
683 \mathrm{~A}-31-\mathrm{CC} \\
683 \mathrm{~A}-32-\mathrm{CC} \\
683 \mathrm{~A}-33-\mathrm{CC} \\
683 \mathrm{~A}-34-\mathrm{CC} \\
683 \mathrm{~A}-35-\mathrm{CC} \\
683 \mathrm{~A}-36-\mathrm{CC} \\
683 \mathrm{~A}-37-\mathrm{CC} \\
683 \mathrm{~A}-38-\mathrm{CC} \\
683 \mathrm{~A}-39-\mathrm{CC}\end{array}$ & $\begin{array}{l}\text { C } \\
F \\
F \\
F \\
F \\
F \\
F \\
R \\
R \\
R\end{array}$ & $\begin{array}{l}\mathrm{M} \\
\mathrm{M} \\
\mathrm{M} \\
\mathrm{M} \\
\mathrm{M} \\
\mathrm{M} \\
\mathrm{M} \\
\mathrm{M} \\
\mathrm{M} \\
\mathrm{M}\end{array}$ & $\begin{array}{l}\mathrm{P} \\
\mathrm{P} \\
\mathrm{P} \\
\mathrm{P} \\
\mathrm{P} \\
\mathrm{P} \\
\mathrm{P}\end{array}$ & P & $?$ & & $\begin{array}{l}\mathrm{P} \\
\mathrm{P} \\
\mathrm{P} \\
\mathrm{P} \\
\mathrm{P} \\
\\
\\
\mathrm{P} \\
\mathrm{P}\end{array}$ & $\begin{array}{l}\mathrm{P} \\
\mathrm{P} \\
\mathrm{P} \\
\mathrm{P} \\
\mathrm{P} \\
\mathrm{P} \\
\mathrm{P} \\
\mathrm{P}\end{array}$ & & $\begin{array}{l}\mathrm{P} \\
\mathrm{P} \\
\mathrm{P} \\
\mathrm{P} \\
\mathrm{P} \\
\mathrm{P} \\
\mathrm{P} \\
\mathrm{P} \\
\mathrm{P}\end{array}$ & $\mathrm{P}$ & & $\begin{array}{l}\mathrm{P} \\
\mathrm{P} \\
\mathrm{P} \\
\mathrm{P} \\
\mathrm{P} \\
\mathrm{P} \\
\mathrm{P} \\
\mathrm{P}\end{array}$ & $\begin{array}{l}\mathrm{P} \\
\mathrm{P}\end{array}$ & $\begin{array}{l}\mathrm{P} \\
\mathrm{P} \\
\mathrm{P} \\
\\
\mathrm{P} \\
\mathrm{P} \\
\mathrm{P} \\
\mathrm{P}\end{array}$ & $\begin{array}{l}\mathrm{P} \\
\mathrm{P} \\
\mathrm{P} \\
\\
\end{array}$ & P & P & $\begin{array}{l}\mathrm{P} \\
\mathrm{P}\end{array}$ & $\begin{array}{l}\mathrm{P} \\
\mathrm{P}\end{array}$ & $\begin{array}{l}\mathrm{P} \\
\mathrm{P} \\
\mathrm{P} \\
\mathrm{P} \\
\mathrm{P} \\
\\
\mathrm{P} \\
\mathrm{P}\end{array}$ & $\begin{array}{l}\mathrm{P} \\
\mathrm{P} \\
\mathrm{P} \\
\mathrm{P} \\
\mathrm{P} \\
\mathrm{P} \\
\mathrm{P}\end{array}$ \\
\hline & $\begin{array}{l}\text { Dorcadospyris } \\
\text { alata }\end{array}$ & $\begin{array}{l}683 \mathrm{~A}-40-\mathrm{CC} \\
683 \mathrm{~A}-41-\mathrm{CC} \\
683 \mathrm{~A}-42-\mathrm{CC} \\
683 \mathrm{~A}-43-\mathrm{CC} \\
683 \mathrm{~A}-44-\mathrm{CC} \\
683 \mathrm{~A}-46-\mathrm{CC} \\
683 \mathrm{~A}-45-\mathrm{CC} \\
683 \mathrm{~A}-48-\mathrm{CC}\end{array}$ & $\begin{array}{l}\mathrm{F} \\
\mathrm{R} \\
\mathrm{R} \\
\mathrm{R}\end{array}$ & $\begin{array}{l}\mathrm{G} \\
\mathrm{M} \\
\mathrm{G} \\
\mathrm{M}\end{array}$ & $\begin{array}{l}\mathrm{P} \\
\mathrm{P}\end{array}$ & $\begin{array}{l}\mathrm{P} \\
\mathrm{P}\end{array}$ & $\mathrm{P}$ & $\mathrm{P}$ & $\mathrm{P}$ & $\begin{array}{l}\mathrm{P} \\
\\
\mathrm{P} \\
\mathrm{P}\end{array}$ & $\begin{array}{l} \\
P \\
P \\
P\end{array}$ & $\begin{array}{l}\mathrm{P} \\
\mathrm{P} \\
\mathrm{P} \\
\mathrm{P}\end{array}$ & $\mathrm{P}$ & $\mathrm{P}$ & $\begin{array}{l}\mathrm{P} \\
\mathrm{P} \\
\mathrm{P}\end{array}$ & P & $\mathrm{P}$ & P & $P$ & $P$ & & & & \\
\hline
\end{tabular}


Hole 683A (continued).

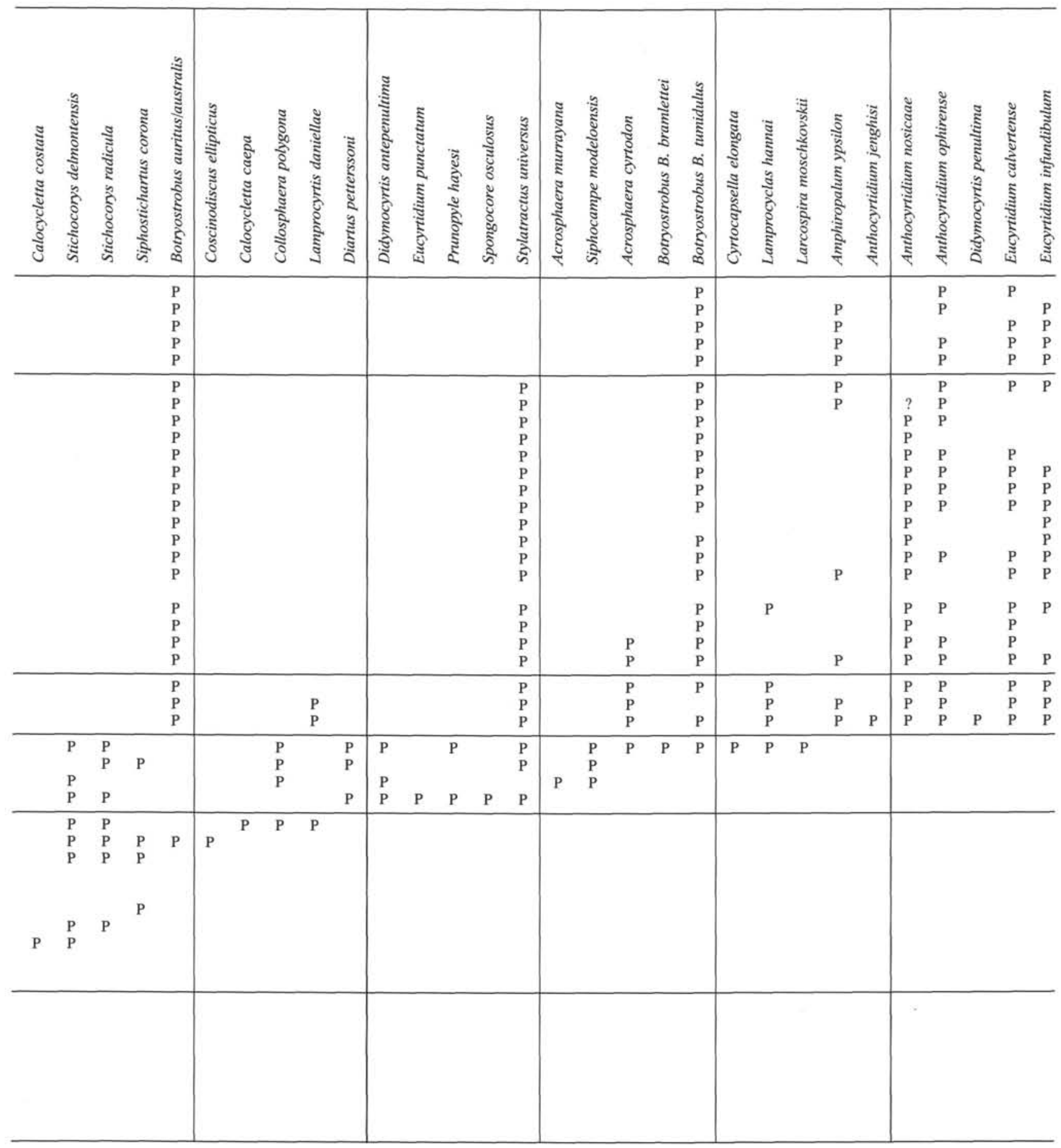


Hole 683A (continued).

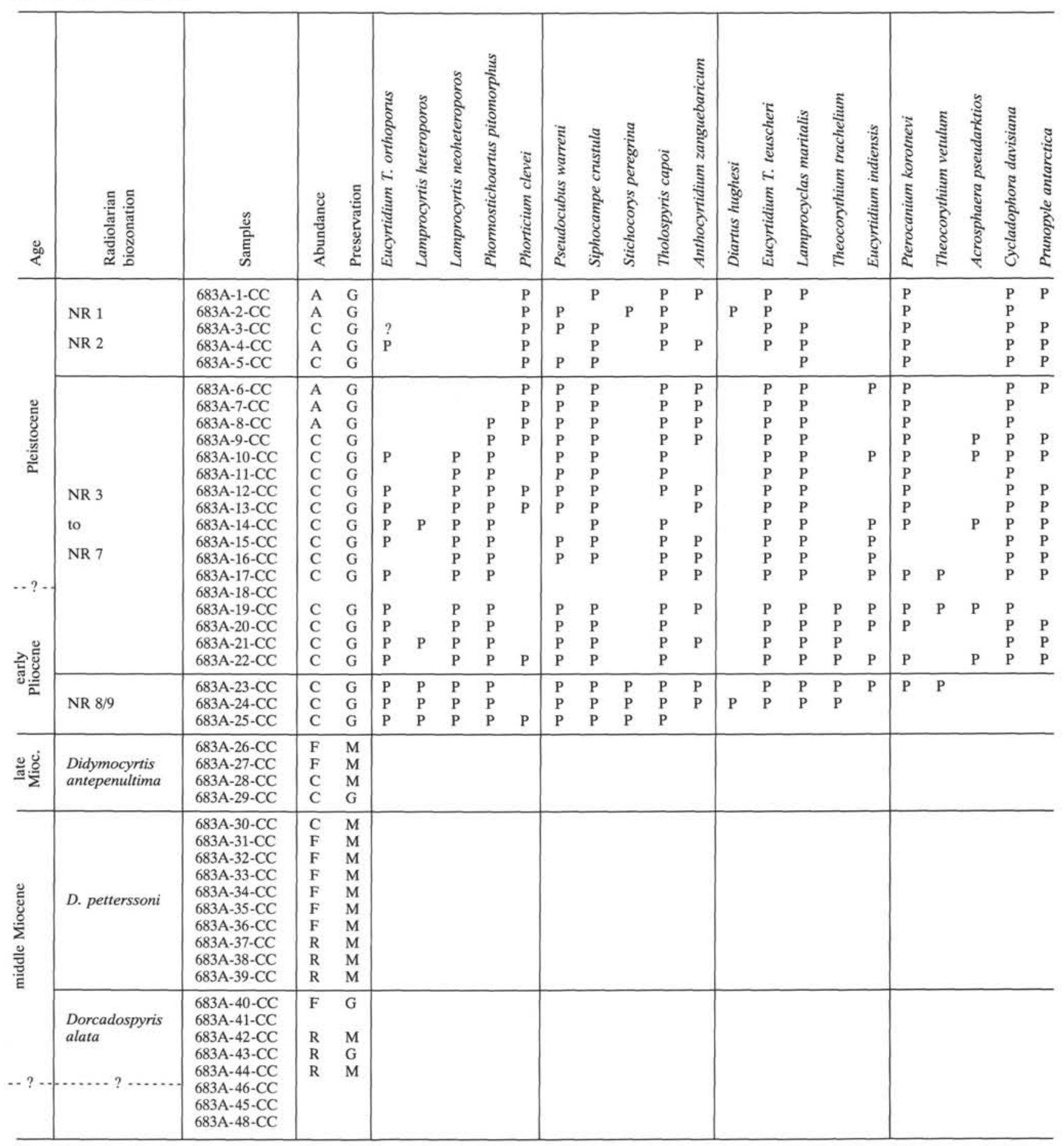


RADIOLARIAN BIOSTRATIGRAPHY ON THE PERU MARGIN

Hole 683A (continued).

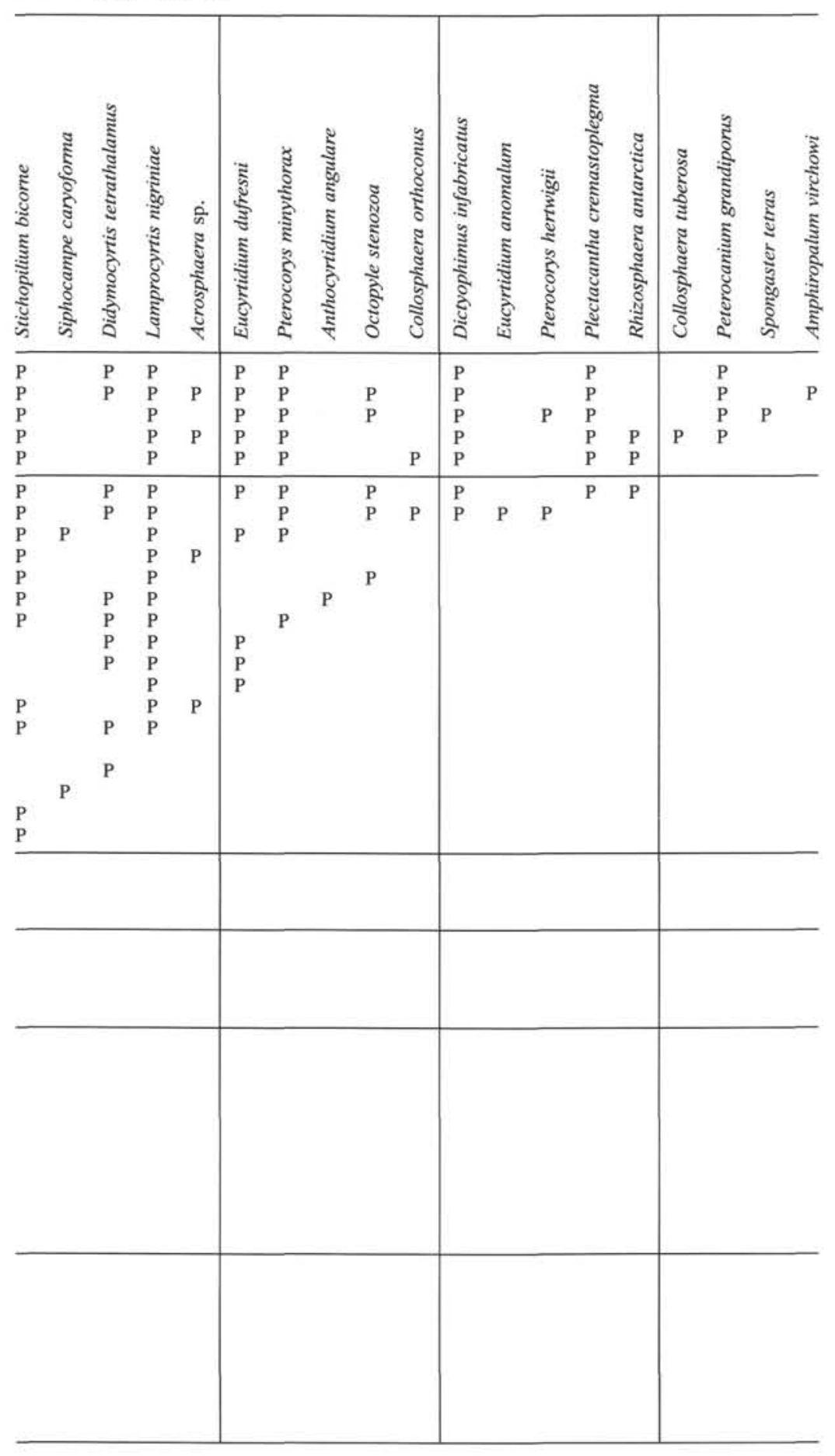

201 
Hole 685A.

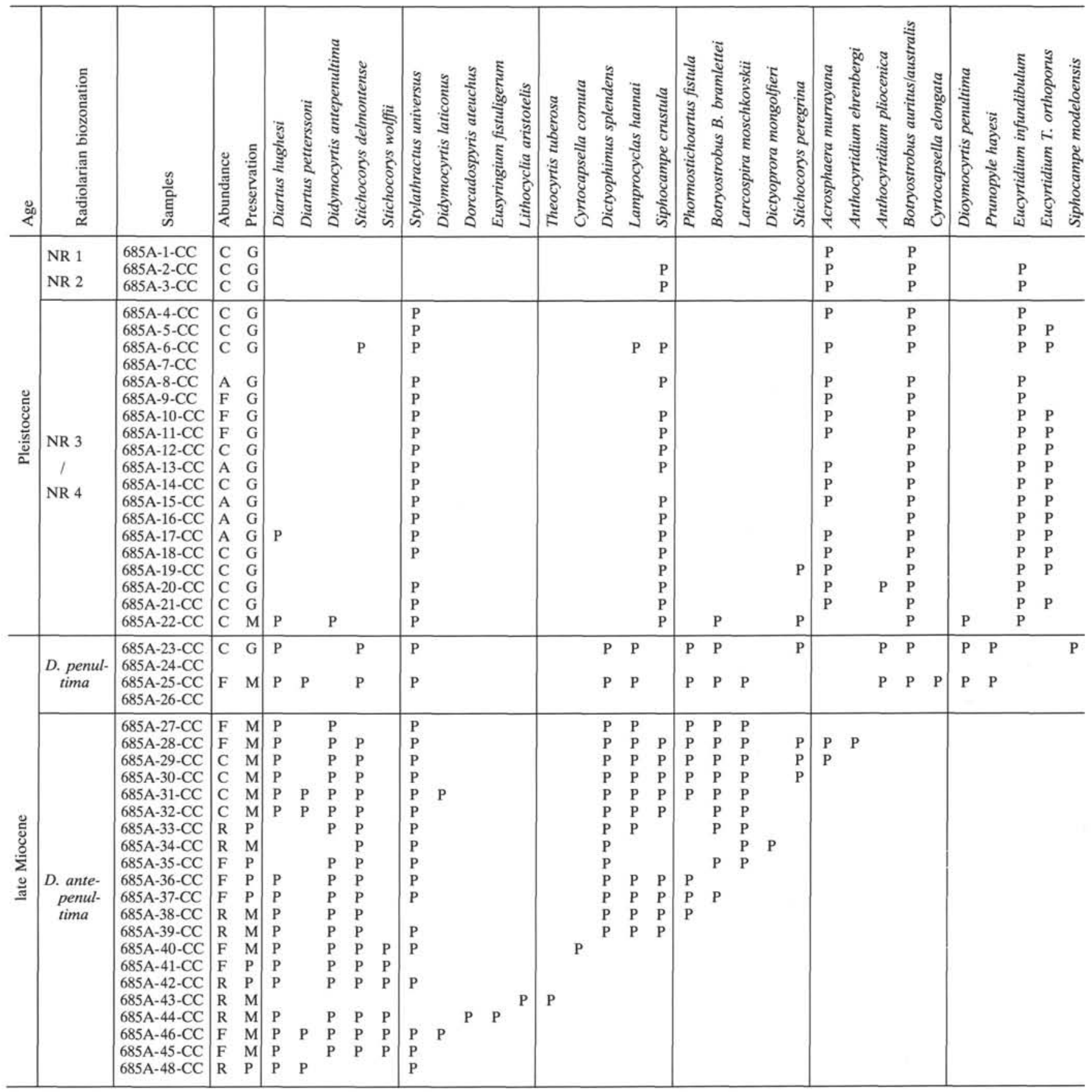


RADIOLARIAN BIOSTRATIGRAPHY ON THE PERU MARGIN

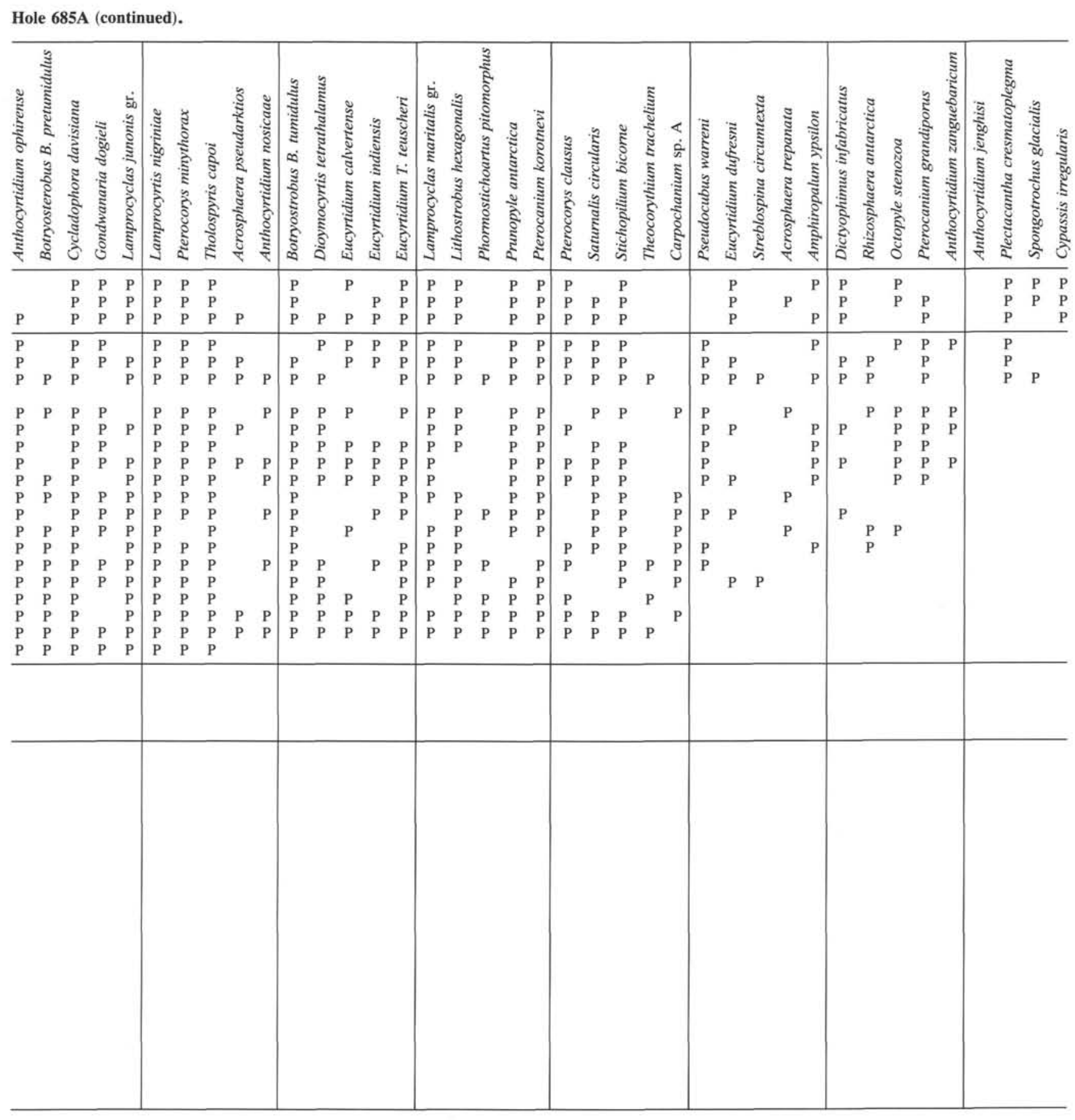

203 
Hole 688A.

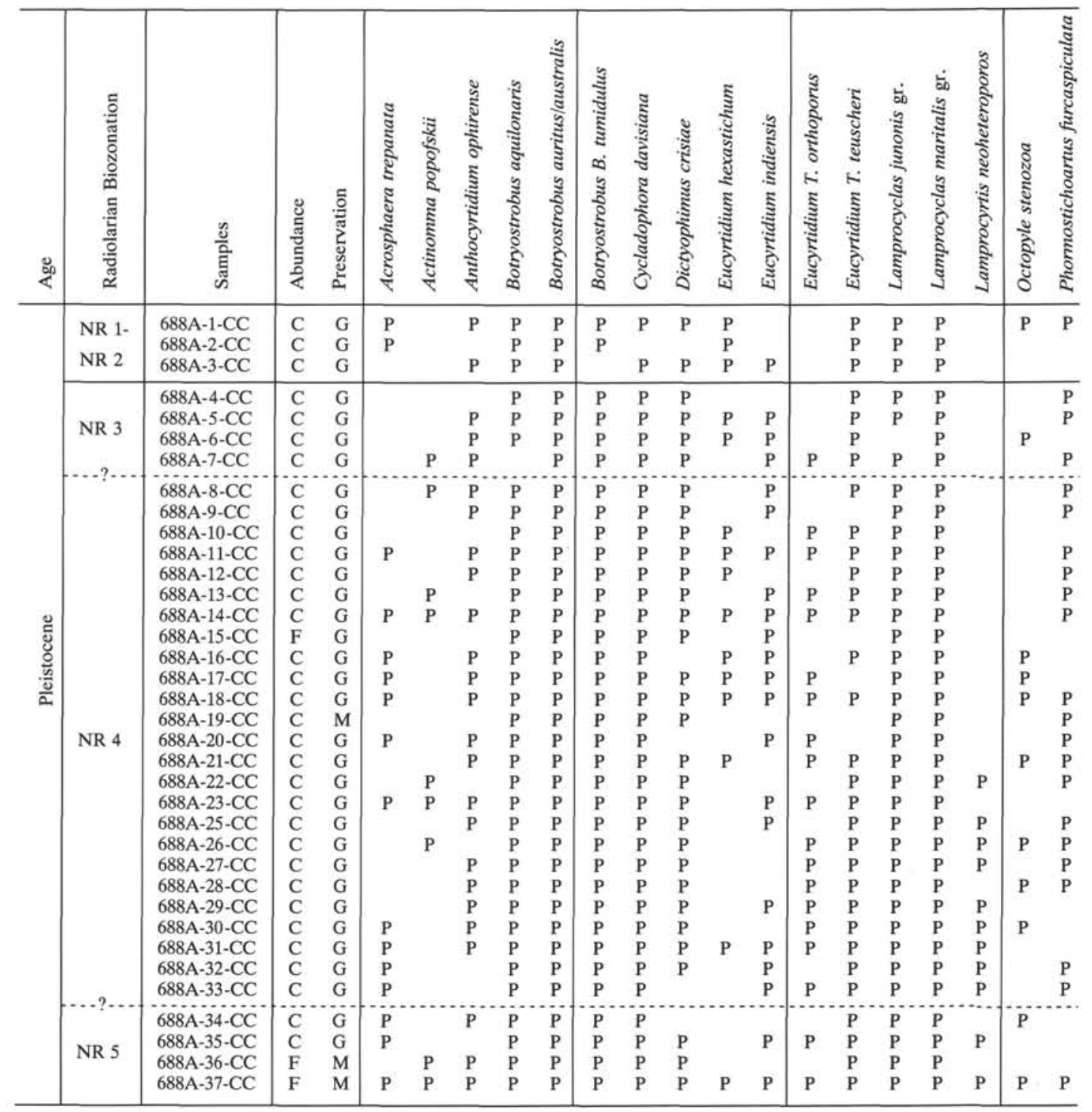


Hole 688A (continued).

\begin{tabular}{|c|c|c|c|c|c|c|c|c|c|c|c|c|c|c|c|c|c|c|c|c|c|c|c|c|c|}
\hline 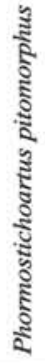 & 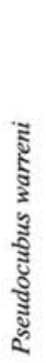 & 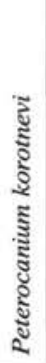 & 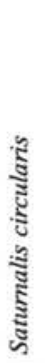 & 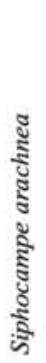 & 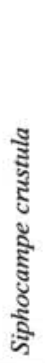 & 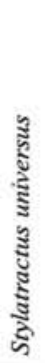 & 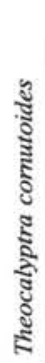 & 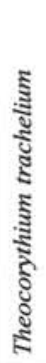 & 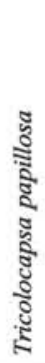 & 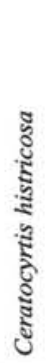 & 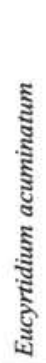 & 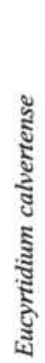 & 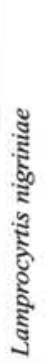 & 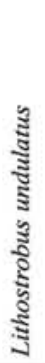 & 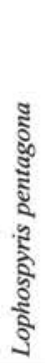 & 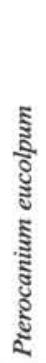 & 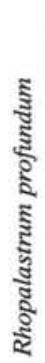 & 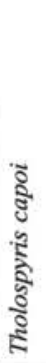 & 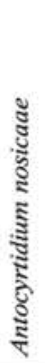 & 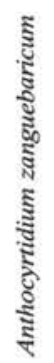 & 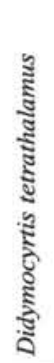 & 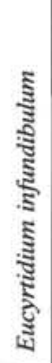 & 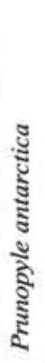 & 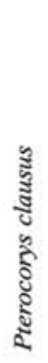 & 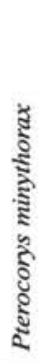 \\
\hline & & $\begin{array}{l}P \\
P\end{array}$ & $\begin{array}{l}P \\
P\end{array}$ & $P$ & $P$ & & P & & P & $\begin{array}{l}\mathrm{P} \\
\mathrm{P} \\
\mathrm{P}\end{array}$ & $\begin{array}{l}P \\
P \\
P\end{array}$ & $\begin{array}{l}P \\
P \\
P\end{array}$ & $\begin{array}{l}\mathrm{P} \\
\mathrm{P} \\
\mathrm{P}\end{array}$ & $\begin{array}{l}\mathrm{P} \\
\mathrm{P} \\
\mathrm{P}\end{array}$ & $\begin{array}{l}P \\
P\end{array}$ & $\begin{array}{l}\mathrm{P} \\
\mathrm{P}\end{array}$ & $\begin{array}{l}\mathrm{P} \\
\mathrm{P} \\
\mathrm{P}\end{array}$ & $\begin{array}{l}\mathrm{P} \\
\mathrm{P} \\
\mathrm{P}\end{array}$ & & $P$ & $\begin{array}{l}\mathrm{P} \\
\mathrm{P} \\
\mathrm{P}\end{array}$ & $P$ & $\begin{array}{l}\mathrm{P} \\
\mathrm{P} \\
\mathrm{P}\end{array}$ & $\begin{array}{l}P \\
P \\
P\end{array}$ & $\begin{array}{l}P \\
P \\
P\end{array}$ \\
\hline & $\begin{array}{l}\mathrm{P} \\
\mathrm{P} \\
\mathrm{P} \\
\mathrm{P}\end{array}$ & $\begin{array}{l}\mathrm{P} \\
\mathrm{P} \\
\mathrm{P} \\
\mathrm{P}\end{array}$ & $\begin{array}{l}\mathrm{P} \\
\mathrm{P} \\
\mathrm{P} \\
\mathrm{P}\end{array}$ & $P$ & $\begin{array}{l}\mathrm{P} \\
\mathrm{P} \\
\mathrm{P} \\
\mathrm{P}\end{array}$ & $\begin{array}{l}\mathrm{P} \\
\mathrm{P} \\
\mathrm{P} \\
\mathrm{P}\end{array}$ & $\begin{array}{l}\mathrm{P} \\
\mathrm{P} \\
\mathrm{P} \\
\mathrm{P}\end{array}$ & & $\begin{array}{l}\mathrm{P} \\
\mathrm{P} \\
\mathrm{P} \\
\mathrm{P}\end{array}$ & $\begin{array}{l}\mathrm{P} \\
\mathrm{P}\end{array}$ & $P$ & $P$ & $\begin{array}{l}\mathrm{P} \\
\mathrm{P} \\
\mathrm{P} \\
\mathrm{P}\end{array}$ & $\begin{array}{l}\mathrm{P} \\
\mathrm{P}\end{array}$ & $\begin{array}{l}\mathrm{P} \\
\mathrm{P}\end{array}$ & $\begin{array}{l}\mathrm{P} \\
\mathrm{P} \\
\mathrm{P} \\
\mathrm{P}\end{array}$ & $\begin{array}{l}\mathrm{P} \\
\mathrm{P} \\
\mathrm{P} \\
\mathrm{P}\end{array}$ & $\begin{array}{l}P \\
P\end{array}$ & & & $\begin{array}{l}P \\
P\end{array}$ & $\begin{array}{l}\mathrm{P} \\
\mathrm{P}\end{array}$ & $\begin{array}{l}\mathrm{P} \\
\mathrm{P} \\
\mathrm{P} \\
\mathrm{P}\end{array}$ & $\begin{array}{l}\mathrm{P} \\
\mathrm{P} \\
\mathrm{P} \\
\mathrm{P}\end{array}$ & $\begin{array}{l}\mathrm{P} \\
\mathrm{P} \\
\mathrm{P}\end{array}$ \\
\hline P & $P$ & $\begin{array}{l}\mathrm{P} \\
\mathrm{P} \\
\mathrm{P}\end{array}$ & $\begin{array}{l}\mathrm{P} \\
\mathrm{P} \\
\mathrm{P}\end{array}$ & & $\mathrm{P}$ & $\begin{array}{l}\mathrm{P} \\
\mathrm{P} \\
\mathrm{P}\end{array}$ & $\mathrm{P}$ & & $\mathrm{P}$ & $\begin{array}{l}\mathrm{P} \\
\mathrm{P} \\
\mathrm{P}\end{array}$ & & $\begin{array}{l}\mathrm{P} \\
\mathrm{P} \\
\mathrm{P}\end{array}$ & $\begin{array}{l}\mathrm{P} \\
\mathrm{P} \\
\mathrm{P}\end{array}$ & $P$ & $\mathrm{P}$ & $\mathrm{P}$ & $\begin{array}{l}\mathrm{P} \\
\mathrm{P} \\
\mathrm{P}\end{array}$ & $P$ & $\begin{array}{l}\mathrm{P} \\
\mathrm{P} \\
\mathrm{P}\end{array}$ & & $\mathrm{P}$ & & $\begin{array}{l}\mathrm{P} \\
\mathrm{P} \\
\mathrm{P}\end{array}$ & $\begin{array}{l}\mathrm{P} \\
\mathrm{P} \\
\mathrm{P}\end{array}$ & \\
\hline & $P$ & $\mathbf{P}$ & & $P$ & $P$ & $P$ & & $P$ & P & & $P$ & $P$ & & & $P$ & $\mathrm{P}$ & & $P$ & & & & $P$ & $P$ & P & $P$ \\
\hline$P$ & $\mathrm{P}$ & $\begin{array}{l}\mathrm{P} \\
\mathrm{P}\end{array}$ & $\begin{array}{l}\mathrm{P} \\
\mathrm{P}\end{array}$ & & $\begin{array}{l}\mathrm{P} \\
\mathrm{P}\end{array}$ & $\begin{array}{l}\mathrm{P} \\
\mathrm{P}\end{array}$ & $\begin{array}{l}\mathrm{P} \\
\mathrm{P}\end{array}$ & & $\begin{array}{l}\mathrm{P} \\
\mathrm{P}\end{array}$ & $\begin{array}{l}\mathrm{P} \\
\mathrm{P}\end{array}$ & $\begin{array}{l}\mathrm{P} \\
\mathrm{P}\end{array}$ & $\begin{array}{l}\mathrm{P} \\
\mathrm{P}\end{array}$ & $\begin{array}{l}\mathrm{P} \\
\mathrm{P}\end{array}$ & $\begin{array}{l}\mathbf{P} \\
\mathrm{P}\end{array}$ & $\begin{array}{l}\mathrm{P} \\
\mathrm{P}\end{array}$ & $\mathrm{P}$ & $\begin{array}{l}\text { P } \\
P\end{array}$ & $P$ & $\begin{array}{l}\mathrm{P} \\
\mathrm{P}\end{array}$ & $P$ & $P$ & $\begin{array}{l}\mathrm{P} \\
\mathrm{P}\end{array}$ & $P$ & $\begin{array}{l}\mathrm{P} \\
\mathrm{P}\end{array}$ & $P$ \\
\hline & P & $\begin{array}{l}\mathrm{P} \\
\mathrm{P}\end{array}$ & $\begin{array}{l}\mathrm{P} \\
\mathrm{P}\end{array}$ & & $\mathrm{P}$ & $\begin{array}{l}\mathrm{P} \\
\mathrm{P}\end{array}$ & $\begin{array}{l}\mathrm{P} \\
\mathrm{P}\end{array}$ & & $\begin{array}{l}\mathrm{P} \\
\mathrm{P}\end{array}$ & $\mathrm{P}$ & P & P & $\begin{array}{l}\mathrm{P} \\
\mathrm{P}\end{array}$ & P & & & $\begin{array}{l}\mathrm{P} \\
\mathrm{P}\end{array}$ & $\begin{array}{l}P \\
P\end{array}$ & $\begin{array}{l}\mathrm{P} \\
\mathrm{P}\end{array}$ & & & & $\begin{array}{l}\mathrm{P} \\
\mathrm{P}\end{array}$ & $\begin{array}{l}\mathrm{P} \\
\mathrm{P}\end{array}$ & \\
\hline & $P$ & $\mathrm{P}$ & $\mathrm{P}$ & & $P$ & $\mathrm{P}$ & $\mathrm{P}$ & & $\mathrm{P}$ & P & $P$ & $\mathrm{P}$ & $\mathrm{P}$ & $\mathrm{P}$ & $P$ & $P$ & $\mathrm{P}$ & $\mathrm{P}$ & & $P$ & $\mathbf{P}$ & $P$ & $\mathrm{P}$ & $\mathrm{P}$ & $\mathrm{P}$ \\
\hline & $P$ & & $P$ & $P$ & $P$ & $P$ & P & $P$ & $P$ & $P$ & P & P & $P$ & & $P$ & $P$ & P & $P$ & $P$ & $P$ & P & & & $P$ & P \\
\hline $\begin{array}{l}\mathrm{P} \\
\mathrm{P}\end{array}$ & $\mathrm{P}$ & $P$ & $\begin{array}{l}\mathrm{P} \\
\mathrm{P}\end{array}$ & $\begin{array}{l}\mathrm{P} \\
\mathrm{P}\end{array}$ & $\begin{array}{l}\mathrm{P} \\
\mathrm{P}\end{array}$ & $\begin{array}{l}\mathrm{P} \\
\mathrm{P}\end{array}$ & $\begin{array}{l}\mathrm{P} \\
\mathrm{P}\end{array}$ & & $\begin{array}{l}\mathrm{P} \\
\mathrm{P}\end{array}$ & $\begin{array}{l}\mathrm{P} \\
\mathrm{P}\end{array}$ & P & P & $\begin{array}{l}\mathrm{P} \\
\mathrm{P}\end{array}$ & $\mathbf{P}$ & $\mathrm{P}$ & & $\begin{array}{l}\mathrm{P} \\
\mathrm{P}\end{array}$ & $\begin{array}{l}\mathrm{P} \\
\mathrm{P}\end{array}$ & P & $\mathrm{P}$ & P & $\begin{array}{l}P \\
P\end{array}$ & $P$ & $\begin{array}{l}\mathrm{P} \\
\mathrm{P}\end{array}$ & $\mathrm{P}$ \\
\hline P & $P$ & $\mathbf{P}$ & $\mathrm{P}$ & & $\mathrm{P}$ & $\mathrm{P}$ & $\mathrm{P}$ & & $\mathrm{P}$ & $\mathrm{P}$ & $\mathrm{P}$ & $P$ & $\mathrm{P}$ & & $\mathrm{P}$ & & $\mathrm{P}$ & $\mathrm{P}$ & $P$ & P & $P$ & $\mathrm{P}$ & $P$ & $\mathrm{P}$ & $P$ \\
\hline P & $\begin{array}{l}\mathrm{P} \\
\mathrm{P}\end{array}$ & $\begin{array}{l}\mathrm{P} \\
\mathrm{P}\end{array}$ & $\begin{array}{l}P \\
P\end{array}$ & $P$ & $\begin{array}{l}\mathrm{P} \\
\mathrm{P}\end{array}$ & $\begin{array}{l}\mathrm{P} \\
\mathrm{P}\end{array}$ & $\begin{array}{l}\mathrm{P} \\
\mathrm{P}\end{array}$ & & P & $\begin{array}{l}\mathrm{P} \\
\mathrm{P}\end{array}$ & P & $\mathrm{P}$ & P & & $\mathrm{P}$ & $P$ & P & $\begin{array}{l}\mathrm{P} \\
\mathrm{P}\end{array}$ & P & $\mathrm{P}$ & P & P & $\begin{array}{l}\mathrm{P} \\
\mathrm{P}\end{array}$ & $\begin{array}{l}\mathrm{P} \\
\mathrm{P}\end{array}$ & $P$ \\
\hline P & $\mathrm{P}$ & & $\mathrm{P}$ & & $\mathrm{P}$ & $\mathrm{P}$ & P & & P & P & P & $P$ & $\mathrm{P}$ & & $P$ & $\mathrm{P}$ & $\begin{array}{l}\text { P } \\
\text { a }\end{array}$ & & $\mathrm{P}$ & $P$ & $P$ & $\mathrm{P}$ & $\mathrm{P}$ & $\begin{array}{l}1 \\
\mathrm{P}\end{array}$ & $P$ \\
\hline P & $\mathrm{P}$ & & $\mathrm{P}$ & $P$ & $\mathrm{P}$ & $\mathrm{P}$ & P & & P & & P & P & $\mathrm{P}$ & & $\mathrm{P}$ & $\mathrm{P}$ & $\mathrm{P}$ & $P$ & $\mathrm{P}$ & $\mathrm{P}$ & P & P & P & P & \\
\hline & $P$ & $\mathrm{P}$ & $P$ & & $P$ & $P$ & $P$ & & $P$ & $P$ & P & P & $P$ & & & $P$ & $P$ & $P$ & $P$ & $P$ & P & & $P$ & $P$ & \\
\hline P & $P$ & $\mathrm{P}$ & P & $P$ & $\mathrm{P}$ & $P$ & P & & P & P & & P & $\mathrm{P}$ & $P$ & & P & P & $P$ & $\mathrm{P}$ & $\mathrm{P}$ & & $P$ & $P$ & $P$ & \\
\hline P & $P$ & $P$ & $P$ & & $\mathrm{P}$ & $\mathrm{P}$ & $\mathrm{P}$ & & $\mathrm{P}$ & $\mathrm{P}$ & P & P & $\mathrm{P}$ & $P$ & & $\mathrm{P}$ & $\mathrm{P}$ & $P$ & $\mathrm{P}$ & $\mathrm{P}$ & & P & $\mathbf{P}$ & $P$ & \\
\hline P & & $P$ & $P$ & & $P$ & $P$ & P & $P$ & $\mathrm{P}$ & P & P & $\mathrm{P}$ & $\mathrm{P}$ & & & & $\mathrm{P}$ & $P$ & & & P & P & $P$ & & \\
\hline P & $P$ & & $P$ & & $\mathrm{P}$ & $\mathrm{P}$ & P & & $\mathrm{P}$ & P & $\mathrm{P}$ & & $\mathrm{P}$ & & $P$ & & $P$ & $\mathrm{P}$ & $P$ & & P & P & & & \\
\hline P & $\mathrm{P}$ & $P$ & P & & $\mathrm{P}$ & $\mathrm{P}$ & P & $P$ & $\mathrm{P}$ & P & P & $P$ & $\mathrm{P}$ & & $\mathrm{P}$ & & $\mathrm{P}$ & $P$ & & & P & P & $P$ & $P$ & \\
\hline P & $\mathrm{P}$ & $\mathrm{P}$ & $\mathrm{P}$ & & $\mathrm{P}$ & $P$ & P & & $\mathrm{P}$ & P & $\mathrm{P}$ & $\mathrm{P}$ & & $P$ & & & P & $P$ & & & P & & $P$ & $P$ & \\
\hline P & $P$ & $P$ & $P$ & & $P$ & $\mathrm{P}$ & P & & P & P & P & & & & $P$ & & P & $P$ & $P$ & & & $P$ & $\mathrm{P}$ & $P$ & \\
\hline $\mathrm{P}$ & & & $\mathrm{P}$ & $\ddot{\mathbf{P}}$ & & $\mathrm{P}$ & $\ddot{\mathrm{P}}$ & & $\mathrm{P}$ & & & $\mathrm{p}$ & $\mathrm{P}$ & & $\mathrm{P}$ & & $\mathrm{P}$ & & $\mathrm{P}$ & & $\mathrm{P}$ & & $\mathrm{P}$ & $\mathrm{P}$ & \\
\hline P & & & $P$ & $P$ & $P$ & $P$ & P & & P & $\mathbf{P}$ & $P$ & & $\mathrm{P}$ & & & $P$ & P & & $P$ & $P$ & P & P & $P$ & $P$ & $P$ \\
\hline P & $\begin{array}{l}\mathrm{P} \\
\mathrm{P}\end{array}$ & P & $\begin{array}{l}\mathrm{P} \\
\mathrm{P}\end{array}$ & P & P & $\begin{array}{l}\mathrm{P} \\
\mathrm{P}\end{array}$ & P & $P$ & P & $\mathbf{P}$ & $P$ & $P$ & $P$ & $\mathrm{P}$ & $\mathrm{P}$ & $\mathrm{P}$ & $P$ & $P$ & & & & & & & \\
\hline
\end{tabular}


Hole 688A (continued).

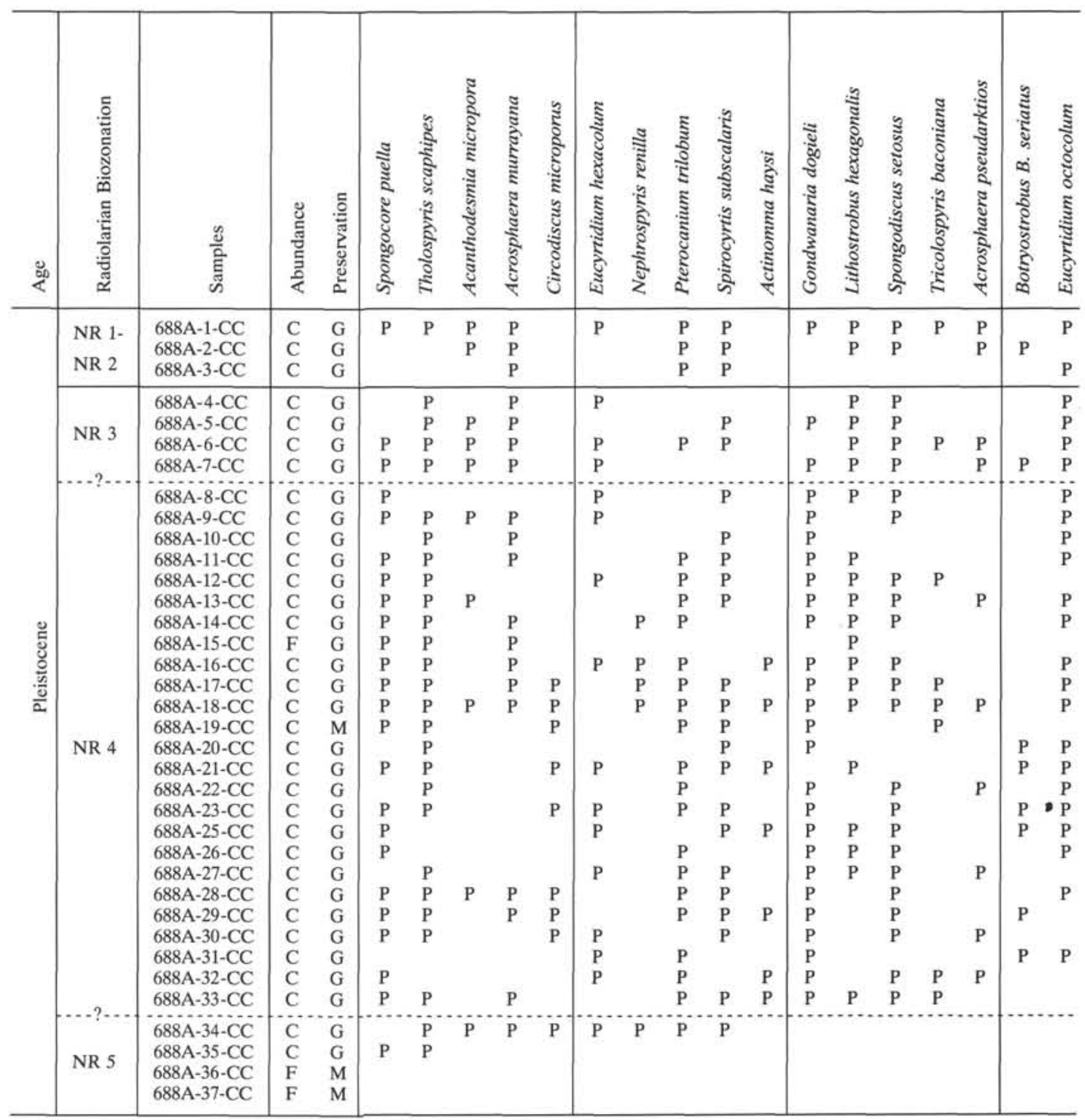


RADIOLARIAN BIOSTRATIGRAPHY ON THE PERU MARGIN

Hole 688A (continued).

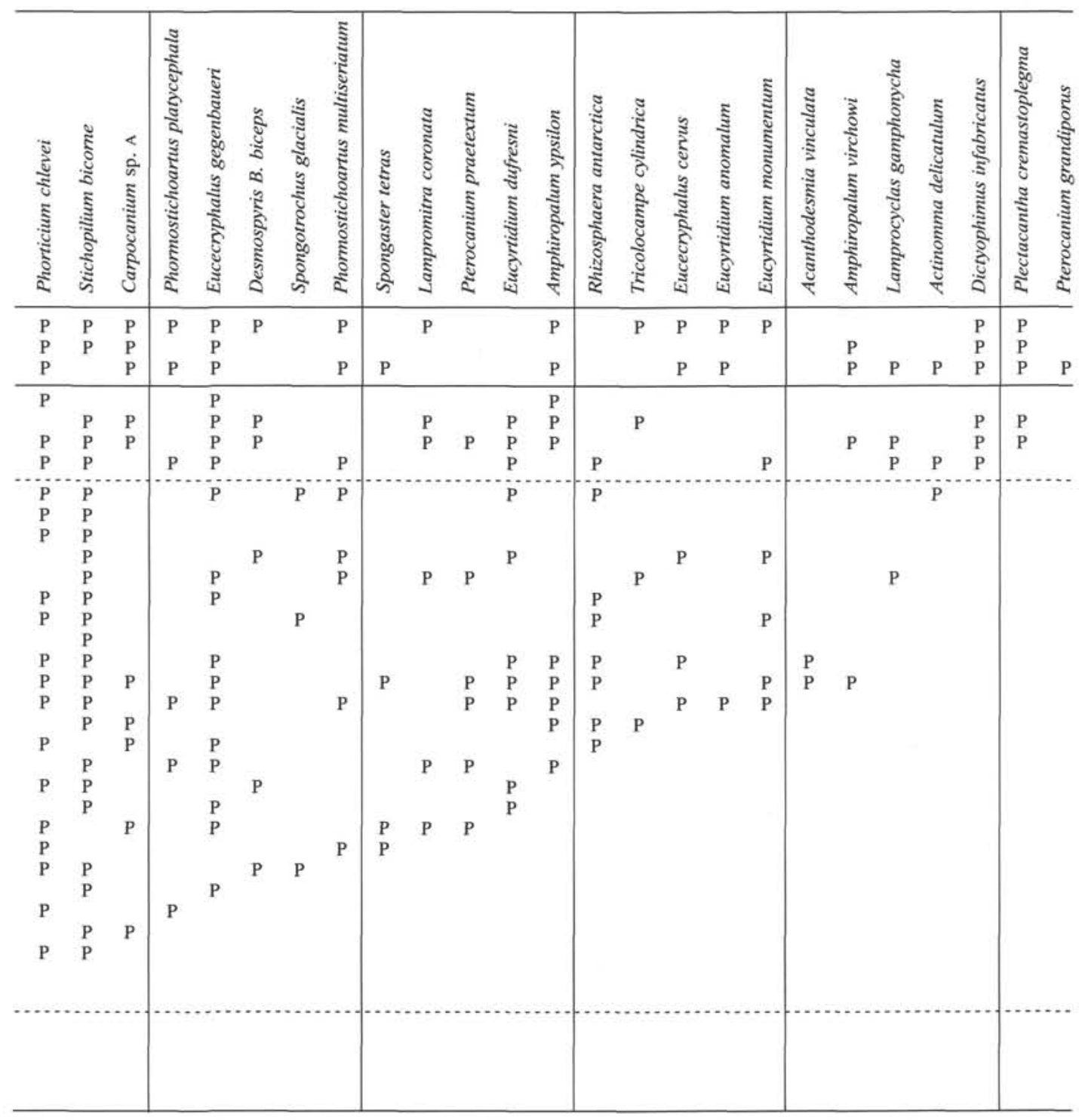

207 